\title{
Formula Apportionment: \\ Factor Allocation and Tax Avoidance
}

Sebastian Eichfelder, Frank Hechtner, Jochen Hundsdoerfer^

- Prof. Dr. Sebastian Eichfelder, Otto von Guericke Universität Magdeburg, Universitätsplatz 2, 39106 Magdeburg, Germany, Tel.: +49 39167 18810, Email: Sebastian.Eichfelder@ovgu.de; Prof. Dr. Frank Hechtner (author of correspondence), Freie Universität Berlin, Garystraße 21, 14195 Berlin, Germany, Tel.: +49 30838522 13, Email: Frank.Hechtner@fu-berlin.de; Prof. Dr. Jochen Hundsdoerfer, Freie Universität Berlin, Garystraße 21, 14195 Berlin, Germany, Tel.: +49 30838522 66, Email: Jochen.Hundsdoerfer@fu-berlin.de, and NoCeT.

We thank an anonymous reviewer, Richard Sansing (editor), Nadja Dwenger, Katharina Finke, Martin Fochmann, Frank Fossen, Martin Jacob, Reinald Koch, Laurence van Lent, Eva Kristina Matthaei, Nadine Riedel, Dirk Schindler, Kerstin Schneider, Sebastian Siegloch, Martin Simmler, Victor Steiner, Caren Sureth, participants of the Kommission Steuerlehre Annual Meeting 2014, participants of the Verein für Socialpolitik, participants of the Ausschuss Unternehmensrechnung Annual Meeting 2014, participants of the NoCeT NHH Bergen Research Seminar 2014, participants of the ZEW Empirical Tax Research Workshop 2014, and participants of the research colloquium 2017 at the Graduate School of Law, Economics, and Society University Würzburg for helpful comments. We thank Marcel Zander for conducting interviews with tax practitioners. For technical support, we are grateful to the Research Data Centres of the Federal Statistical Office and the statistical offices of the Länder (Berlin-Brandenburg), especially Katja Baum, Steffi Dierks, Anja Hlawatsch, Julia Höninger, Steffen Lauf, Matthias Klumpe and Ramona Voshage.

Paper accepted by Richard Sansing; received: November 2015; accepted: July 2017 


\title{
Formula Apportionment: \\ Factor Allocation and Tax Avoidance
}

\begin{abstract}
This paper addresses the question of how firms react to tax incentives in a formula apportionment (FA) tax regime. Under FA, the profits of all consolidated entities of a business group are summed and then allocated according to a formula based on FA factors. We hypothesize that firms may change the allocation of real production factors and/or manipulate the FA factor through tax avoidance strategies. Analysing FA tax effects of the German local business tax with payroll expense as the exclusive FA factor, we find empirical evidence consistent with both hypotheses. Regarding the allocation of production factors, we observe significant tax effects on labour input at the intensive margin but not on labour input at the extensive margin. In addition, we find evidence of an indirect FA spillover effect on capital investment. Our findings on tax avoidance proxies are consistent with tax-induced manipulations of payroll expense as an FA factor to save tax payments.
\end{abstract}

Keywords: Factor Allocation, Formula Apportionment, Profit Shifting, Tax Avoidance JEL Classification: H32, H71, H73, J61 


\section{Introduction}

Using firm data at the establishment level, this paper empirically analyses the impact of a payroll formula apportionment (FA) regime on business activity. Under FA, the profits of all consolidated entities of a business group are summed and then allocated according to a formula based on measurable proxies for inputs and/or outputs (e.g., payroll expense, sales, fixed assets). Due to the difficulties in calculating arm's length prices for intra-group transactions and the resulting opportunities for firm tax base erosion and profit shifting (Dharmapala, 2014), FA has been suggested as an alternative for the separate accounting (SA) regime in international taxation (Altshuler \& Grubert, 2010; Clausing, 2013; Gresik, 2010; Nielsen, Raimondos-Møller, \& Schjelderup, 2010). Examples include unitary taxation in the U.S. and Canada and the concept of the Common Consolidated Corporate Tax Base (CCCTB) of the European Union.

While there is considerable empirical research on the incentive effects of SA tax regimes (see Feld \& Heckemeyer, 2011, for tax effects on foreign direct investment and Dharmapala, 2014, for research on tax avoidance using profit shifting strategies), few studies address the impact of FA on business activity (e.g., Gupta \& Mills, 2002). Most of these studies analyse the U.S. unitary taxation regime using state-level data (Clausing, 2016; Goolsbee \& Maydew, 2000; Gupta \& Hofmann, 2003; Klassen \& Shackelford, 1998; Lightner, 1999; Weiner, 1996). Hence, our knowledge of FA effects at the firm and establishment level is limited. As a result, attempts to assess the budgetary and firm-specific consequences of introducing FA instead of SA typically do not account for behavioural responses (Clausing \& Lahav, 2011; Devereux \& Loretz, 2008; Hines, 2010; Shackelford \& Slemrod, 1998). ${ }^{1}$

From a theoretical perspective, an FA-based income tax can be interpreted as a tax upon the FA factors of the apportionment formula (McLure, 1981). It follows that FA factor allocations are distorted by tax rate differences (Gordon \& Wilson, 1986). In line with this argumentation, recent research on the German local business tax, for which payroll is the exclusive FA factor, interprets correlations between tax rates and payroll costs as evidence for a distortion in real business activity (e.g., Riedel, 2010; Thomsen, Ullmann, \& Watrin, 2014). An important assumption in this research is that FA tax

1 An exception is the simulation of Altshuler and Grubert (2010). However, due to the lack of empirical research on FA, their simulations are not based on empirically-based estimates but on hypothesized tax elasticities. 
effects are not caused by "artificial" tax avoidance strategies (Clausing, 2013; Martini, Niemann, \& Simons, 2012; Riedel \& Runkel, 2007). Clausing and Lahav (2011) argue, "While accounting manipulations can easily shift profits of low-tax countries under a SA system, that is not the case under a formulary system." By contrast, the German practitioner literature documents a wide range of tax avoidance strategies for the FA system of the German local business tax (Dietrich \& Krakowiak, 2009; Scheffler, 2011; Urbahns, 2010). A primary method of these strategies is the manipulation of the distribution of payroll expenses among business units, which is the exclusive FA factor in the German regime (see Section 2). ${ }^{2}$

We address these issues through detailed analysis of the impact of the German local business tax's FA regime on (1) the allocation of real labour input at the extensive and intensive margins, (2) spillover effects on investment and output, and (3) tax avoidance strategies affecting payroll expense but not real input and/or output. German municipalities impose the German local business tax with substantial variation in tax rates in the cross section and over time. Our analysis is based on a unique firm panel data set with detailed information on the FA factor (payroll expense), real labour input (number of employees, number of hours worked), capital input (investment expense), and output (sales) at the establishment level. This comprehensive data set provides a greater level of detail to our investigation of FA effects on business activity compared to existing empirical studies. An additional benefit of our analysis is that payroll expense is the only FA factor in the German local business tax. Therefore, we can identify spillover effects on output (measured by sales) and capital input (measured by investment expense).

As a preliminary analysis, we confirm existing German research providing evidence for a negative correlation between the tax rate differential (difference between the tax rate of establishment $i$ and the average tax rate) and payroll expense as the FA factor (Riedel, 2010; Thomsen et al., 2014). While Riedel (2010) and Thomsen et al. (2014) are limited to the FA impact on payroll expense, we extend the analysis to three different sets of measures: (1) measures of real labour input (number of employees, number of hours worked), (2) measures of a manipulation of the payroll expense (ratio

2 For example, businesses may "lease" employees from low-tax establishments to high-tax establishments, as such leasing contracts will not increase the FA-relevant payroll expense in high-tax municipalities. Further, businesses may "outsource" employees working in high-tax jurisdictions to subsidiaries that are not part of the FA scheme. 
between payroll expense and measures of real input or output) and (3) measures of FA spillover effects on related variables (sales and capital investment). We benefit from a unique database that provides much more detailed information at the establishment level than data used in previous studies.

Tax effects on payroll expense may operate through different channels, including relocation of labour input at the extensive margin (number of employees), relocation of labour input at the intensive margin (number of hours worked per employee), and manipulation of payroll expense via tax avoidance. Previous research implicitly assumes that a significant correlation between payroll expense and the tax rate differential implies an impact of the FA tax system on the number of employees (reallocation of labour input at the extensive margin). We show in our paper that this conclusion may not be correct. While we find a negative correlation of the tax rate differential with (a) payroll expense (overall effect) and (b) the number of hours worked (labour input at the intensive margin), we do not find a statistically significant correlation of the tax rate differential with the number of employees (labour input at the extensive margin). This finding supports a new interpretation of the results of Riedel (2010) and Thomsen et al. (2014).

We also find a significant correlation between the tax rate differential and proxy variables for (artificial) tax avoidance. Therefore, our research presents indirect evidence that the correlation between payroll expense and the tax rate differential is driven not only by reallocation of real input factors but also by tax-planning strategies that manipulate the payroll expense at the establishment level without affecting the production process or the allocation of input factors. This outcome challenges assertions in the literature that FA taxation may be robust to aggressive tax avoidance strategies.

Furthermore, we analyse whether FA tax incentives result not only in a distortion of the apportionment factor (payroll expense) but also in spillover effects on establishmentlevel capital input. For the small-group sample (firms with fewer than four establishments per entity), we find evidence for an FA-driven spillover effect on capital investment. Therefore, FA tax effects distort not only labour input but also capital input 
as a complementary production factor. ${ }^{3}$ This analysis is the first to identify corresponding spillover effects.

Our paper enriches the existing literature in several ways. First, extending the scarce literature on firm reactions to FA, we investigate not only the overall FA effect on payroll expense but also the different transmission channels of this effect. While the U.S.-based literature provides evidence for FA tax effects on employment (Goolsbee \& Maydew, 2000; Lightner, 1999) and investment (Gupta \& Hofmann, 2003; Weiner, 1996), firm-level evidence on the transmission channels is lacking. Complementing existing research using firm-level tax data (Riedel, 2010; Thomsen et al., 2014), we are the first to provide evidence of a distortion of real production factors at the firm level. In so doing, we find a significant impact on the number of hours worked but not on the number of employees. An explanation for this outcome might be the strong legal protections for German employees (e.g., dismissal protection regulations; see Forsyth, 2009; Sá, 2008), which limit the ability of German employers to engage in tax-driven labour force adjustments. As a result, FA tax effects on payroll expense do not necessarily imply physical reallocation of employees. Taking into account the strong employee protection legislation in most European countries (Sá, 2008), similar effects might be expected for a CCCTB at the European level.

Second, this is the first paper to provide evidence for spillover effects of the FA labour input distortion on investment. Our results suggest that FA tax regimes may distort not only the corresponding FA factors but also other related variables. This finding should be relevant for the on-going theoretical debate over which factors are optimal for an FA scheme (Anand \& Sansing, 2000; Gresik, 2010; Nielsen et al., 2010; Riedel \& Runkel, 2007; Runkel \& Schjelderup, 2011). For example, if labour and capital are closely correlated as complements, the opportunities for FA tax policy to attract capital investment via a low weight on capital as an FA factor would be limited.

Third, we are the first to analyse whether firms use more or less "artificial" tax avoidance strategies under a payroll-based FA regime to manipulate FA factors. Whereas it is challenging to find direct evidence for FA tax avoidance, our results on

In unreported regressions for firms with only two establishments (two-establishment subsample), we also find weak evidence for spillover effects of labor input on output (measured by sales). However, this outcome is not robust in our baseline specification and should be interpreted with caution. 
tax avoidance proxies are consistent with a tax-induced manipulation of payroll expense as an FA factor. While the allocation of income among jurisdictions under SA tax regimes is strongly affected by multinationals' profit shifting strategies (Dharmapala, 2014), FA has been regarded as less vulnerable to tax avoidance practices (Altshuler \& Grubert, 2010; Clausing, 2013; Clausing, 2016; Clausing \& Lahav, 2011; Martini et al., 2012; Riedel \& Runkel, 2007). Taking into account evidence on FA tax avoidance for the sales factor in the U.S. (Gupta \& Mills, 2002; Klassen \& Shackelford, 1998), payroll expense may appear to be a particularly suitable and tax planning-robust apportionment factor. However, as documented by Buettner, Riedel, and Runkel (2011), firms may use the consolidation rules of an FA regime to optimally rely either on FA or on SA (as FA is only relevant for consolidated firms). Extending these findings, we generate evidence consistent with firms manipulating the distribution of payroll expense under the FA scheme to minimize their tax burden. Thus, the introduction of FA will presumably not "stop" tax avoidance strategies but rather change tax avoidance techniques. Hence, our paper also contributes to the broad literature on tax avoidance (Hanlon \& Heitzman, 2010) via its focus on avoidance mechanisms under an FA scheme. While our paper is based on the German FA system, our findings should also be relevant for FA systems of other countries (e.g., Canada, Switzerland, U.S.) and for considerations regarding a European FA system.

Our paper proceeds as follows. In Section 2, we present the German local business tax and the corresponding FA regulations. Section 3 presents our theoretical considerations and hypotheses. Section 4 introduces the empirical strategy and the data. The results are reported in Section 5. Finally, we present our conclusions in Section 6.

\section{The German local business tax and FA}

The domestic business profits of the majority of German firms are subject to a local business tax. ${ }^{4}$ While the German parliament and the Federal Council of Germany enact a uniform tax code, each German municipality has the authority to set the local business tax rate. The large number of municipalities we consider (12,266 over the sample period) guarantees sufficient variation in tax rates for our analysis. The local business tax rate is calculated using a uniform basic rate (German: Messzahl, 3.5\% since 2008)

4 Exceptions exist for sole proprietorships and partnerships with earnings from agriculture, forestry and learned academic professions (e.g., self-employed doctors, tax advisers, architects, engineers). These types of businesses are not taxed by the German local business tax. 
and a variable local business tax multiplier (German: Hebesatz). Figure 1 provides an overview of the distribution of local business tax rates in Germany in 2008, which is the final year of our data set. We observe considerable variation in tax rates in the cross section.

[Figure 1 about here]

In 2004, a minimum local business tax multiplier of $2(200 \%$, as described by the German Local Business Tax Code) was introduced. The German business tax reform of $2008 / 2009$ slightly reduced the basic rate from $5 \%$ to $3.5 \%$ and abolished the tax deductibility of the local business tax from taxable profit. ${ }^{5}$ In the year 2008 , local business tax rates have typically ranged from $7 \%$ (local tax multiplier of 2 ) to $17.15 \%$ (local tax multiplier of 4.9). There are very few outliers (current maximum rate is $31.5 \%$, in Dierfeld). Accounting for the higher basic rate of 5\% and the tax deductibility of the local business tax from its own tax base, historical tax rates before 2008 were slightly higher $(9.09 \%$ for a tax multiplier of 2 and $19.68 \%$ for a local tax multiplier of 4.9). The local business tax base is a modified firm profit. The most important current modification is the nondeductibility of a fraction of interest, leases, and rents paid (before 2008, only nondeductibility of a fraction of interest for long-term debt). To avoid double taxation, there are also exemptions for distributed profits and dividends.

For our identification strategy, a crucial feature of the local business tax is the FA system with payroll as the exclusive FA factor. For firms with multiple establishments in different German municipalities (hereafter, multi-establishment firms), the local business tax base is usually apportioned according to the establishments' payroll shares. ${ }^{6}$ Hence, firms file a partition statement (in German "Zerlegungserklärung") that provides information on the distribution of payroll among establishments in different municipalities. In consolidated tax groups, subsidiaries are also treated as establishments. The relevant payroll per employee is limited to $€ 50,000$ for FA purposes. Trainees' wages, tax-exempt wage payments, and profit-related bonuses are disregarded for FA purposes. The local business tax base must be declared to the state tax authorities, which calculate and allocate the local business tax and perform random

5 Before 2008, the German local business tax payments therefore reduced the tax base of the (corporate and/or personal) income tax and its own tax base.

6 Under certain conditions (e.g., wind power stations), there are also special apportionment schemes, which are not based on payroll expense (Scheffler, 2011). Considering their limited scope of application, these special regimes are not relevant for our analysis. 
tax audits. Usually, tax audits are not conducted by the municipalities but by the German states. Therefore, the German fiscal authorities have no strong incentive to audit the allocation of local business taxes to different municipalities (Becker \& Fuest, 2010; Gresik, 2010). Anecdotal evidence (Scheffler, 2011) suggests a weak audit system for the German FA scheme.

The German practitioner literature discusses a range of tax avoidance strategies to manipulate payroll expense as an FA factor (Dietrich \& Krakowiak, 2009; Scheffler, 2011). To obtain a better understanding of tax avoidance opportunities in the German FA system, we rely on a series of qualitative interviews with a focus on tax-planning and audit procedures. Overall, we use 19 interviews with tax advisers, business taxpayers, staff members of tax authorities and staff members of municipal authorities. ${ }^{7}$ Importantly, this qualitative research confirms anecdotal evidence of a weak tax audit system for FA purposes. Hence, the fiscal administration and the municipal authorities have only very limited opportunities to check the validity of the payroll distribution reported in a firm's partition statement. This is partially driven by the fact that firms' central offices administer employee contracts, while the establishment is not a legally distinct entity. As a result, there exist no official documents on the workplaces of employees and no official accounts on the distribution of payroll among establishments.

Using the tax practitioner literature, as well as the findings of our own qualitative research, we were able to identify tax-planning strategies for FA factor manipulation. One example for such tax planning is that an establishment in a low-tax municipality leases employees to other establishments or subsidiaries of the same firm group that are located in high-tax municipalities. The other business units pay a leasing fee for the employees. However, this leasing fee is not considered a payroll expense under German FA rules. As a result, the FA-relevant payroll expense is paid in a low-tax municipality, while the hours worked are performed in a high-tax municipality. This increases (reduces) the weight of low-tax (high-tax) municipalities in the FA formula.

In many practical cases, tax avoidance "techniques" might be much simpler than the leasing scheme. A main driver is the information asymmetry between the tax authority/municipality and the business taxpayer. As it is extremely difficult for German authorities to check information in FA partition statements, firms might simply

Marcel Zander conducted the interviews as part of a related project. We are very thankful to Marcel Zander for supporting this research. 
"officially" reallocate payroll expense across different establishments. Payroll is typically paid by the headquarters and not by the establishment itself, while employees may be active in more than one establishment. Hence, a staff member might effectively work at one establishment but officially be paid by another establishment. Note that such "errors" are not necessarily regarded as illegal or tax fraud. They might simply be regarded as accounting errors or discretion.

A further opportunity is that establishments in high-tax municipalities buy business services from low-tax establishments. This strategy has similar implications to the leasing scheme. While employees are officially employed in low-tax establishments, they are effectively working in high-tax municipalities. Such outsourcing is not relevant for FA and increases the weight of low-tax establishments in the FA scheme. The identified FA tax-planning strategies are consistent with evidence on tax-motivated cost allocation (Yetman, 2001). As an alternative, employees might also be outsourced to subsidiaries, which are not part of the FA regime (non-consolidation for FA tax purposes) and can therefore be used for profit shifting in an SA context.

From an empirical perspective, the German local business tax has a number of notable advantages when testing the impact of FA systems on real business activity. First, the German local business tax uses payroll expense as the single FA factor, which simplifies the analysis and permits the identification of spillover effects on investment and sales. Second, the Local Business Tax Code is uniform in all German municipalities. Therefore, we may focus simply on the variation in tax rates to identify the impact of FA on the allocation of labour input. Third, we observe substantial variation in tax rates over time and in the cross section. Tax rates range from $0 \%$ (before 2004) to more than $30 \%$ over the period considered. On average, approximately $8 \%$ of the 12,266 municipalities change their local business tax rate each year, providing sufficient variation in tax rates over time. This is documented in Figure 2.

[Figure 2 about here]

\section{Theory and hypotheses}

As McLure (1981) suggests, income taxes raised by FA can be interpreted as taxes on the corresponding FA factors. In the case of Germany, payroll expense is the only FA factor. Thus, the average local business tax rate $\tau$ of a multi-establishment firm is the weighted sum of tax rates $\tau_{i}$, with the payroll share of an establishment $i$ as the weighting factor. Corresponding to the theoretical literature (Anand \& Sansing, 2000; 
Gordon \& Wilson, 1986; Nielsen et al., 2010), the tax rate will distort the FA factor cost and, consequently, the factor input. Therefore, we focus on Payroll share in $_{\text {of }}$ establishment $i$ (= Payroll expense $e_{i} / \sum_{j=1}^{J}$ Payroll expense $_{j}$ with the aggregate number of establishments $J$ ).

We use the tax rate differential $\operatorname{Tax}_{i}$ as a measure of FA tax incentives. $\operatorname{Tax} D_{i}$ is defined as the difference between the tax rate of establishment $i, \tau_{i}$, and the unweighted average tax rate over all other establishments $k \neq i, K=J-1$ of the same entity $\left(\operatorname{Tax}_{i}=\tau_{i}-\sum_{k=1, k \neq i}^{K} \frac{\tau_{k}}{K}\right) \cdot{ }^{8}$ Since a positive (negative) tax rate differential creates an incentive to shift payroll from (into) the establishment, we hypothesize:

H1: $\quad$ The Payroll share of an establishment $i$ is negatively correlated with the tax rate differential.

While the literature (e.g., Riedel, 2010; Thomsen et al., 2014) interprets the correlation between Payroll share and the tax rate differential solely as evidence for a reallocation of real labour inputs, this is not the only possible response from taxpayers. As Dietrich and Krakowiak (2009), Urbahns (2010), Scheffler (2011) and our own qualitative research demonstrate, there is a wide range of FA tax avoidance strategies that affect payroll expense without changing real labour inputs. Further, existing evidence does not provide information on the channels involved in a reallocation of production factors at the firm level (Goolsbee \& Maydew, 2000; Gupta \& Hofmann, 2003; Lightner, 1999; Riedel, 2010). To identify the impact of the German FA local business tax regime on real labour inputs, we rely on measures of labour input at the extensive and intensive margins.

Similar to Payroll share, we use the share of employees at establishment $i$ to the total number of employees (Employee share) as a measure of labour input at the extensive margin. For labour input at the intensive margin, we use the ratio of hours worked per

8 Riedel (2010) uses a weighted tax rate differential with sales as a weighting factor. However, in our study, such a measure would not be appropriate because we further consider spillover effects on sales and investments. Thus, sales might also be distorted by FA tax incentives. In addition, it remains questionable if FA tax incentives are better represented by a weighted tax rate differential or by an unweighted tax rate differential, as in our case. 
employee at establishment $i$ to the sum of hours worked per employee across all

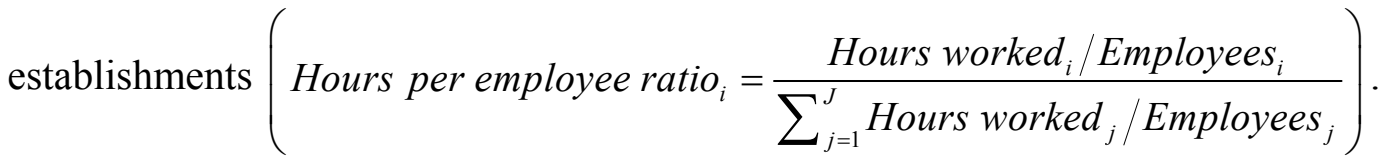

While this ratio is not a "share" in the true sense, it is a relative measure ranging from zero to 1. Thus, it has similar statistical properties (e.g., mean, standard error; see Table 4) to our "share" measures (Payroll share, Employee share), which simplifies the comparability of regression results. We assume that both measures of real labour input are negatively affected by the shifting incentive measured by the tax rate differential.

H2a: The Employee share of an establishment $i$ is negatively correlated with the tax rate differential.

H2b: The Hours per employee ratio of an establishment $i$ is negatively correlated with the tax rate differential.

In addition, we analyse spillover effects of labour inputs on output and capital input. Assuming a Cobb-Douglas production function with output (sales) $S_{i}\left(L_{i} ; K_{i}\right)$ depending on labour input and capital input and a positive cross-derivative of both input factors $\left(\frac{\partial S_{i}}{\partial L_{i} \partial K_{i}}>0\right)$, an adjustment of labour input $L_{i}$ will result in a corresponding adjustment of output $S_{i}$ and capital input $K_{i}$. For example, if German FA tax incentives reduce labour input, we should also observe a reduction in output and capital input. Since the German FA scheme does not consider sales or capital stock as FA factors, both proxies for real business activity should be unaffected by tax avoidance strategies intended to manipulate the FA factor (payroll expense).

We identify these indirect effects of the German FA regime by investigating the correlation between TaxD and Sales share (ratio of the sales of establishment $i$ to the total sales of the firm) as well as TaxD and Investment share (ratio of gross investment in equipment and real estate at establishment $i$ to the total gross investment of the firm). As profits from foreign operations may be tax-exempt under certain conditions, ${ }^{9}$ Sales share is based on sales from domestic operations. However, we also perform a robustness check that includes sales from both domestic and foreign operations.

9 Corresponding to $\S 2$ of the German Local Business Tax Code (German: Gewerbesteuergesetz), the tax is relevant only for ongoing business operations in Germany. 
Investment share is based on gross investment, since our database does not provide information on the capital stock at the establishment level. Investment share also accounts for leasing contracts for new equipment and real estate. We assume that these secondary spillover effects of $\operatorname{Tax} D$ via labour input are delayed by one period. Therefore, we use the lagged value of $\operatorname{Tax} D$ in both cases.

H3a: The Sales share of an establishment $i$ is negatively correlated with the oncelagged tax rate differential.

$H 3 b$ : The Investment share of an establishment $i$ is negatively correlated with the once-lagged tax rate differential.

Finally, we also analyse tax avoidance strategies of German businesses manipulating the distribution of the FA factor without changing the real factor allocation. We assume that tax avoidance will affect payroll expense while leaving real labour input or output unchanged. Therefore, we investigate correlations between the tax rate differential and the ratio of payroll expense to real labour input or output. Following the approach of the Hours per employee ratio, we use the following two measures.

We use first the ratio of payroll expense per hours worked of establishment $i$ to the sum of payroll expense per hours worked for all establishments,

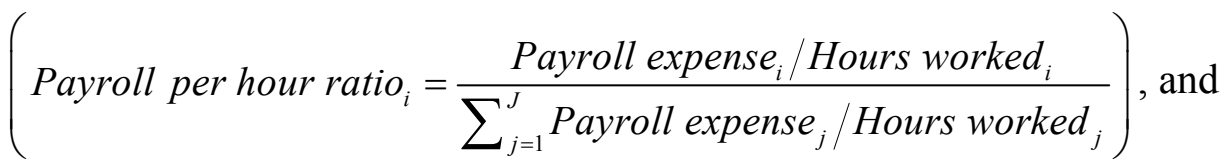

second, the ratio of payroll expense per unit of sales of establishment $i$ to the sum of payroll expense per unit of sales for all establishments of the firm

$$
\left(\text { Payroll per sales ratio }_{i}=\frac{\text { Payroll expense }_{i} / \text { Sales }_{i}}{\sum_{j=1}^{J} \text { Payroll expense }_{j} / \text { Sales }_{j}}\right) .
$$

An assumption of our identification strategy is that measures of real input and output (hours worked, sales) are not affected or manipulated by tax avoidance practices. As suggested by the tax practitioner literature and our own qualitative research, we expect that German businesses adjust their tax avoidance strategies to tax rate changes without a significant time delay and hypothesize a negative correlation with the current tax rate differential:

H4a: The Payroll per hour ratio of an establishment $i$ is negatively correlated with the tax rate differential. 
H4b: The Payroll per sales ratio of an establishment $i$ is negatively correlated with the tax rate differential.

\section{Empirical strategy and data}

In our empirical tests, we regress payroll expense at the establishment level on tax rate differentials to test H1. We use the share of payroll expense of establishment $i$ of the

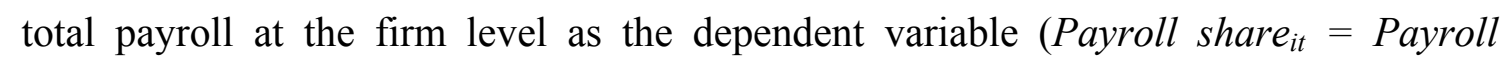

expense $_{i t} / \sum_{j=1}^{J}$ Payroll expense ${ }_{j t}$ ). A benefit of this scaled variable is that it should not be affected by general payroll changes at the firm level that are unrelated to the allocation of payroll across establishments. The Payroll share of establishment $i$ in year $t$ is regressed on the tax rate differential $\operatorname{Tax}_{i t}$ as a measure of the tax incentive and covariates

Payroll share $_{i t}=\beta_{0}+\beta_{1} \cdot \operatorname{Tax}_{i t}+\varepsilon \cdot E_{i t-2}+\delta \cdot D_{i t}+\lambda_{t}+\alpha_{i}+u_{i t}$

with the error term $u_{i t}$. Tax $D_{i t}$ is defined as documented in Section 3 (for the definition of variables, see also Table 1). We consider year fixed effects $\lambda_{t}$ to account for economic trends and shocks and establishment fixed effects $\alpha_{i}$ to control for unobserved heterogeneity in the establishments. Thus, our identification strategy relies on changes in the tax rate differential.

$E_{i t-2}$ is a vector of establishment controls encompassing twice-lagged Sales share it-2 $_{2}$ and Investment share it-2 $_{2}$ to account for the growth of establishments and changes in establishment size. If current payroll is associated with future payroll (as we safely can assume), then unobserved factors may confound the association between tax incentives and payroll variables. For example, there might be a positive trend in the payroll expense of an establishment and simultaneously a positive trend in tax rates over time that could confound the expected negative impact of taxes on Payroll share ${ }_{i t}$.

We use second lags instead of first lags for establishment controls. As local business tax rate changes may be announced and anticipated, controlling for first lags may lead to inconsistent regression results. As an example, consider a tax reform in a municipality increasing $\operatorname{Tax} D_{i t}$. If this reform is previously announced and/or anticipated, it could

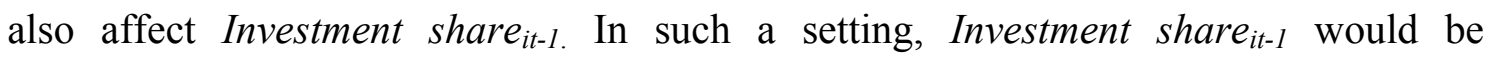
correlated with $\operatorname{Tax} D_{i t}$ and therefore endogenous. Thus, controlling for Investment share $_{i t-1}$ would block a causal path (impact of the reform on Investment share it-1 $_{\text {) }}$ and lead to inconsistent regression results. 
Nickell (1981) shows that panel models with lagged dependent variables as controls provide inconsistent regression results if individual fixed effects are included (in our case establishment fixed effects). To account for this bias, we abstain from including (twice-) lagged dependent variables as right-hand-side variables throughout the paper.

$D_{i t}$ is a vector of control variables at the district level that includes unemployment (local unemployment rate in percentage points), GDP per capita (logarithm of price-adjusted GDP per capita in euros) and population (logarithm of the number of inhabitants) in a district. $^{10}$ For district-level information, regional economic development is not significantly affected by developments at the establishment level. Therefore, endogeneity should be a minor issue for district information. Hypotheses $\mathrm{H} 2$ a through $\mathrm{H} 4 \mathrm{~b}$ are tested by regression models corresponding to (1).

As dependent variables $Y_{i t}$, we use Employee share $_{i t}$ for H2a, Hours per employee ratio it for H2b, Sales share $i t$ for H3a, Investment share ${ }_{i t}$ for H3b, Payroll per hour ratio it for $\mathrm{H} 4 \mathrm{a}$ and Payroll per sales ratio it $_{\text {for }} \mathrm{H} 4 \mathrm{~b}$. Since we assume delayed spillover effects, we use a once-lagged TaxD $D_{i t-1}$ for Sales share $i t$ and Investment share $i t$. Accounting for a potential "Nickell bias", we do not include twice-lagged values of the dependent variable as establishment controls in models with Sales share ${ }_{i t}$ and Investment share ${ }_{i t}$ as

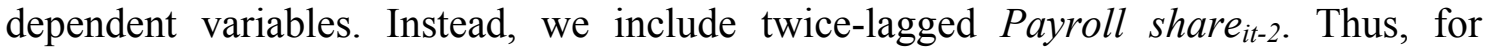
Investment share $_{i t}$ (Sales share $\left.i t\right)$ as the dependent variable, establishment controls are Sales $_{\text {share }_{i t-2}}$ (Investment share $_{i t-2}$ ) and Payroll share $_{i t-2}$. Documentation on the regression variables can be found in Table 1.

[Table 1 about here]

A problem for our analysis stems from the ambiguity of tax avoidance incentives for firms with a large number of establishments. For example, a firm with five establishments, one of which is in a high-tax municipality, has the opportunity to shift payroll expense from the high-tax establishment to four other establishments, as well as among these four other establishments. In a world without non-tax costs, the firm would simply reallocate payroll to the establishment with the lowest local business tax rate. However, the reallocation of payroll generates non-tax costs (e.g., costs associated with

10 Apart from the municipality, the district ("Kreis") is the smallest regional administrative body in Germany. For German cities, the district is often identical to the municipality (in German "kreisfreie Städte"). This holds for all larger German cities and for small, regionally important German cities (e.g., Ansbach, Gera, Magdeburg, Straubing). Hence, controlling for changes in economic trends at the district level is well suited to our identification strategy. 
production inefficiency) and tax avoidance costs (e.g., tax adviser fees, tax avoidance risk), which are not observable in our data. In addition, alternative tax avoidance strategies (e.g., from the implicit option between SA and FA as discussed by Buettner et al., 2011) should be more valuable for larger entities with a typically large number of establishments. Therefore, the identification of FA tax effects is more difficult for firms with a larger number of establishments. Accordingly, our main focus is on a subsample with a low number of establishments. To account for different payroll shifting incentives for firms with many establishments and to generate subsamples of sufficient size, we employ a subsample of entities with up to three establishments (small-group sample, 52,542 observations) and a subsample of entities with four or more establishments (large-group sample, 38,136 observations). The small-group sample should be best suited for a detailed analysis of the various FA effects. The large-group sample, however, may suffer from downward bias due to measurement error associated with the tax incentive variable.

As database, we use the German AFiD panel (German: Amtliche Firmendaten in Deutschland) for the manufacturing and mining industries ${ }^{11}$, which represents approximately one-quarter of the gross value added of the German economy (Destatis, 2015). The AFiD panel comprises several mandatory business surveys conducted by the German Federal Statistical Office (German: Statistisches Bundesamt) and can be accessed by remote-data processing (Malchin \& Voshage, 2009). The surveys in question, conducted between 1995 and 2008, are the Investment Survey and the Monthly Report for Manufacturing and Mining Enterprises (both conducted at the establishment level). ${ }^{12}$ We rely on the Monthly Report for payroll expense, number of employees, and the number of hours worked per establishment; we rely on the Investment Survey for investment in equipment and real estate at the establishment level.

The definition of establishments in the database is very close to that under German tax law. Thus, we can rule out the possibility that subsidiaries of a firm group are regarded as establishments in our data. Using the German Statistics of Tax Multipliers (German:

11 The official title of the data is "Research Data Centres of the Federal Statistical Office and the statistical offices of the Länder, AFiD panel for the manufacturing and mining industries, 1995-2008"; see also http://www.forschungsdatenzentrum.de/bestand/afid-panel industriebetriebe/index.asp.

12 The German titles of the surveys are as follows: "Investitionserhebung bei Betrieben des Verarbeitenden Gewerbes sowie der Gewinnung von Steinen und Erden" and "Monatsbericht bei Betrieben des Verarbeitenden Gewerbes sowie der Gewinnung von Steinen und Erden". 
Statistik der Hebesätze) and Regio-Stat information, we complement these data with local business tax rates at the municipality level and information on the economic situation at the district level (GDP per capita, population, unemployment rate). This provides us with a unique panel of establishment data covering the period from 1995 to 2008.

Compared to other firm panels such as Compustat or AMADEUS, AFiD possesses a number of major advantages for our analysis. Unlike public accounting data, the Investment Survey and the Monthly Report provide very detailed information on the volume and composition of payrolls, investments, and sales, and these data are collected at the establishment level. Since we complement the data with information on local business tax rates, we are able to analyse not only correlations between payroll expense and tax rates but also correlations with number of employees, number of hours worked per employee, sales, gross investment, and measures of tax avoidance (payroll per number of hours worked, payroll per unit of sales) at the establishment and firm levels. To the best of our knowledge, this is a unique feature, allowing us to conduct a much more detailed analysis than in previous research. Both surveys are conducted as a mandatory census of all domestic establishments in the manufacturing and mining industries with at least 20 employees; therefore, non-response and sample selection are not issues. An additional advantage stems from the fact that the data are anonymized and available only for political and scientific use. Hence, there should be a lesser incentive for survey participants to "massage the numbers" than in balance sheet information.

A disadvantage of the data is that it does not provide information on firm ownership or holding structures. Thus, we obtain data for the various establishments of one entity but not for subsidiaries or parent companies of that entity. While the data should be excellently suited to analyse factor allocations within a legally distinct entity, they do not enable us to address FA tax incentives in group taxation regimes. As described by Section 2, subsidiaries in consolidated group structures can be regarded as establishments under certain requirements for purposes of the German local business tax (see Buettner et al., 2011). In addition, we are not able to identify other forms of tax avoidance among different legally distinct entities of a consolidated group (e.g., profit shifting between different legal entities). Further, the data are restricted to the manufacturing industry and the mining sector, and they provide information only on gross investment but not on the capital stock. 
The original data include 691,822 observations from the period 1995-2008 for business establishments that participated in the Investment Survey and the Monthly Report and provide both firm and establishment IDs. In a first step, we exclude all firms with only a single establishment, as FA incentives are exclusively relevant for multi-establishment business units. As mentioned before, the data do not permit the identification of FA tax incentives of consolidated group structures. Second, we drop all observations with missing information on our variables (including lagged variables). Our final sample comprises 90,678 observations of multi-jurisdictional establishments in the German manufacturing and mining sectors. Given that we use twice-lagged control variables, we lose two observation years. Thus, we effectively rely on the time period 1997-2008. Table 2 shows the number of firms and the number of establishments for the full sample (Panel A) and the small-group sample (Panel B). In the full sample (small-group sample) the average number of establishments per firm is 3.12 (2.21).

[Table 2 about here]

In Table 3, we display the development of tax rates over time. During the period 19972007 , we observe a small but steady increase in the average local business tax rate. The 2008 tax reform led to a general tax cut, mainly due to a reduction of the basic rate from $5 \%$ to $3.5 \%$ (see Section 2). As this 2008 tax cut is linear for every municipality, it should not jeopardize our identification strategy. The majority of local business tax rate changes are increases. The average tax increase is 0.69 percentage points, which is $4.46 \%$ of the average tax rate. However, during the period 1997-2007, we still find, on average, 153 local business tax rate cuts per year. The average tax cut is 0.65 percentage points, which is $4.18 \%$ of the average tax rate.

[Table 3 about here]

Table 4 reports descriptive statistics for the full sample of the price-adjusted establishment data. For price adjustment to the year 2005, we use the German producer price index for the manufacturing industry (German Council of Economic Experts, 2011). Due to the confidentiality policies of the German Federal Statistical Office, we are not allowed to report maximum and minimum values.

[Table 4 about here]

The descriptive statistics indicate significant variance and a skewed distribution of establishment size. While the average price-adjusted sales per establishment amount to $€ 38.9$ million, the median is only $€ 6.7$ million. On average, establishments spent 
approximately $9 \%$ of sales on gross investment and approximately $22 \%$ on payroll expense. The average number of employees (approximately 319) and the median number of employees (approximately 82) document the size of the establishments. Note that employee numbers are reported on a monthly basis in our data. Therefore, the median value of 82 describes the median of the average number of employees in an establishment over the whole year. On average, each employee works 135.5 hours per month. Descriptive statistics for the tax rate differential show a relatively equal distribution of positive and negative tax incentives over the 90,678 establishments. The average $\operatorname{Tax} D$ is almost zero, and the number of observations with positive $\operatorname{Tax} D$ is very close to the number of observations with negative $\operatorname{TaxD}$. For the various "share" and "ratio" variables of $\mathrm{H} 1$ through $\mathrm{H} 4 \mathrm{~b}$, we find similar statistical properties. Mean values range from 32.8\% (Payroll per sales ratio) to 35.1\% (Payroll share) and standard deviations from $20.0 \%$ (Investment share) to $32.3 \%$ (Payroll per sales ratio).

[Table 5 about here]

Descriptive statistics of the small-group sample ( $<4$ establishments) and the remaining large-group sample ( $\geq 4$ establishments) are provided in Table 5. Establishments in both subsamples are very similar to one another with respect to monthly hours worked per employee, the local business tax rate, the tax rate differential, and regional economic characteristics (e.g., unemployment rates). Differences exist for establishment size and the allocation of input and output variables among different business units. Establishments of large-group firms are larger in terms of sales, gross investment and payroll expense. Further, driven by the higher number of establishments, mean values of our relative "share" and "ratio" variables are smaller. Due to the greater heterogeneity in the large-group sample, the standard deviations of our regression variables (e.g., Payroll share) are relatively high compared to mean values.

\section{$5 \quad$ Results}

\section{$5.1 \quad$ FA effects on payroll expense}

As a first step, we estimate regression model (1) to confirm existing evidence of a negative and significant correlation between the tax rate differential (TaxD) and Payroll share (Riedel, 2010; Thomsen et al., 2014). In so doing, we address the question of whether the correlation becomes more obvious for the subsample of firms with few establishments (small-group sample). Therefore, we estimate (1) for a) the full sample, b) the small-group sample ( $<4$ establishments), and c) the large-group sample $(\geq 4$ 
establishments). We also estimate models for the full sample including an interaction term of TaxD and a measure of group size. Hence, we test whether tax effects in the large-group sample differ significantly from the results of the small-group sample. As variables for group size, we consider a dummy variable for the small-group sample (Small group), the number of establishments (Establishments), and the logarithm of the number of establishments (LN(Establishments)). The group-size-specific tax effect is identified by the interaction term of group size and TaxD (e.g., TaxD $x$ Small group).

Estimations are performed by ordinary least squares (OLS) with establishment and year fixed effects. We use heteroscedasticity-robust standard errors, which are clustered at the establishment level (so-called Rogers standard errors). We report the within $\mathrm{R}^{2}$ and the adjusted $\mathrm{R}^{2}{ }^{13}$ In contrast to the within $\mathrm{R}^{2}$, the adjusted $\mathrm{R}^{2}$ also considers the explanatory power of the establishment fixed effects. Thus, for the calculation of adjusted $\mathrm{R}^{2}$, establishment fixed effects are interpreted as control variables as suggested by Equation (1). The results are reported in Table 6.

[Table 6 about here]

Confirming findings from the literature (Riedel, 2010; Thomsen et al., 2014) and H1, we obtain a negative and significant correlation between TaxD and Payroll share. Corresponding to our estimate for the full sample (1), increasing TaxD by 1 percentage point reduces Payroll share by 0.43 percentage points. While we obtain a somewhat higher coefficient for the small-group sample (-0.678), there is no evidence for a $\operatorname{TaxD}$ effect for the large-group sample. Thus, $\operatorname{Tax} D$ has less explanatory power for firms with a large number of establishments. Nevertheless, the models that include interaction terms do not provide significant evidence of stronger FA effects for firms with a low number of establishments. While the coefficient of TaxD remains stable in models (4) to (6) in Table 6, none of the tested interaction terms is significant.

Calculating semi-elasticities, the results of models (4) to (6) are well in line with the coefficients of TaxD in models (1) and (2). Based on a simulation of payroll shifting between establishments (see Appendix A), we find that a one-percentage-point increase in the tax rate of establishment $i$ reduces the payroll expense of $i$ by $1.36 \%$ (small-group sample) or $1.29 \%$ (full sample). This suggests an average payroll reduction of

13 All estimates and the within $\mathrm{R}^{2}$ are calculated with the $\mathrm{Stata}{ }^{\circledR} \mathrm{xtreg}$ command. The $\mathrm{xtreg}$ command is more conservative for clustered standard errors than the areg command. As the xtreg command does not calculate adjusted $\mathrm{R}^{2}$, we used the areg command for calculating the reported adjusted $\mathrm{R}^{2}$ only. 
establishment $i$ of $€ 87,846$ (small-group sample) or $€ 110,920$ (full sample), which is shifted to the other establishment $j$ if the local business tax rate for $i$ is increased by one percentage point. These estimates should be interpreted carefully as they depend on the assumptions of our simulation approach. Concluding, the results of Table 6 suggest that FA tax effects can be more easily identified in the small-group sample. However, considering the elasticity estimates and insignificant interaction terms of $\operatorname{Tax} D$ and group size, the models do not generate evidence of a difference in FA tax effects between the small-group sample and the large-group sample.

\subsection{Factor allocation, spillover effects, and tax avoidance}

Let us now turn to our main analysis of FA effects on factor allocation and tax avoidance. As described in Section 3, we use six variables as measures of FA effects on business activity. While FA effects on real labour input at the extensive margin and at the intensive margin are measured by Employee share and Hours per employee ratio, FA spillover effects on output and investment are considered through Sales share and Investment share. Finally, tax avoidance strategies affecting payroll expense without affecting real labour input or output are identified by Payroll per hour ratio and by Payroll per sales ratio. Considering Table 6, our main focus is on the small-group sample with the more robust regression results for Payroll share. The results are provided in Table 7. Notwithstanding, we also report results for the full sample (see Table 8). As documented in Table 6, there is no evidence of a TaxD effect for the largegroup sample. Hence, we abstain from reporting results.

[Table 7 about here]

While the TaxD coefficient on Employee share in Table 7 is insignificant, the value of the TaxD coefficient on Hours per employee ratio of -0.634 is close to that of the TaxD coefficient on Payroll share and significant. Hence, we generate empirical evidence for an impact of FA on real labour inputs at the establishment level. This effect is driven by an adjustment of hours worked. We do not find evidence that the effect is driven by an adjustment of the labour force (as suggested by Goolsbee \& Maydew, 2000; Lightner, 1999). This outcome is robust for many different specifications including regressions for the full sample (Table 8) and robustness checks (Subsection 5.3). Thus, our evidence does not support the interpretation of Riedel (2010) and Thomsen et al. (2014) that the impact of the German FA scheme on Payroll share is mainly driven by adjustments of the number of employees. 
A potential explanation for our finding is the institutional structure of the German labour market. Compared to the U.S., Germany has strong employment protection rules for businesses with at least 10 employees. In addition, unions have a strong position in the German labour market, and worker participation is an important aspect of the German corporate governance system (Forsyth, 2009; Sá, 2008). Thus, it may well be that the German labour force is not flexible enough to be strongly affected by an FA tax incentive.

Regarding FA spillover effects, we use once-lagged $\operatorname{Tax} D$ as the dependent variable to account for a delay of the indirect effects. We calculate an insignificant coefficient for Sales share and a negative and significant coefficient for Investment share. Hence, while we find evidence for spillover effects of labour input on investment, the results for spillover effects on output are inconclusive. ${ }^{14}$ Our findings suggest that labour and capital are, on average, complementary input factors.

The negative and significant coefficient estimates for Payroll per hour ratio and Payroll per sales ratio are consistent with our theoretical argument that firms may rely on more or less artificial tax avoidance strategies to optimize Payroll share as the relevant FA factor. The results in Table 7 suggest that firms have two ways to react to FA tax incentives in the German local business tax. First, they adjust real labour inputs (such as the number or working hours) with spillover effects on investment activity. As such reallocation strategies lead to a distortion of the production process, they should be connected with significant costs. Second, firms also seek alternative (artificial) ways to adjust Payroll share without changing or distorting the production process.

Comparing the regression coefficients for Payroll per sales ratio (1.271) and Payroll per hours ratio (-0.546) in the small-group sample with the coefficient for Hours per employee ratio (-0.634) indicates that tax avoidance may be responsible for a significant part of the overall impact of TaxD on Payroll share. ${ }^{15}$ However, considering that

14 In an unreported cross-check, we also tested the impact of TaxD on Sales share only for firms with two establishments (two-establishment subsample with 38,126 observations). In these regressions, we obtain a negative regression coefficient, which is significant at the $10 \%$ level. However, the corresponding results are not robust if we consider the small-group sample or the full sample.

15 One might argue that part of the lower Payroll per hour ratio might be due to a reduction in overtime hours and the corresponding overtime compensation. Taking into account that a one-percentage-point increase in the tax rate reduces the Hours per employee ratio by 0.634 percentage points and the Payroll per hour ratio by almost the same value (0.546 percentage points), the impact of overtime compensation should be almost negligible. Adjusting hours worked by a small amount (e.g., $0.6 \%$ ) will not result in a notable change in the average payroll over all hours worked. Even for an extremely 
Payroll per sales ratio and Payroll per hours ratio are not perfect measures for tax avoidance practices, the relative sizes of both effects should be interpreted carefully. For example, these measures are not adequate to account for all tax avoidance practices (e.g., the use of profit shifting instead of a manipulation of the FA factor). We conclude that both strategies (changes in the allocation of real labour inputs, tax avoidance practices) should be relevant.

Based on the approach presented in Appendix A, we are able to provide a quantitative interpretation of the results in Table 7. In our calculations, we generally assume that payrolls and investments are shifted from the high-tax establishment to the low-tax establishment. We find that an increase in the tax rate differential by one percentage point reduces business investment by $1.04 \%$ (or $€ 31,282$ on average in 2016 prices), the number of hours worked per employee by $1.27 \%$ (or the number of working hours per employee and month by 1.7 hours), the ratio of payroll expense to sales by $2.54 \%$, and the ratio of payroll per hour by $1.09 \%$. Taking into account that the impact of the hours per employee and the impact of the payroll per hour enforce each other, we obtain an overall tax effect on payroll of $-2.35 \%$ as an upper bound estimate.

Considering our regression results in Table 6 (lower bound estimate), our findings suggest that the semi-elasticity of $\operatorname{Tax} D$ with regard to payroll expense for the smallgroup sample lies in a range from $-1.36 \%$ to $-2.35 \%$. Due to methodological differences, a comparison of this range with existing German research is not straightforward. We concentrate on Riedel (2010), as the paper by Thomsen et al. (2014) is a work in progress and reports a very wide range of estimates. Including all control variables, Riedel (2010) finds a semi-elasticity for the payroll to capital ratio of $-1.85 \%$. Assuming a constant capital stock, this can be interpreted as a rough estimate of the tax impact on payroll. This estimate fits very well with the average of our lower bound estimate and our upper bound estimate for the small-group sample $(-1.85 \%=(-1.36 \%+-2.35 \%) / 2)$ and is slightly higher than our estimate from Table 6 for the full sample $(-1.29 \%){ }^{16}$ Considering the differences between data sets and regression techniques, our estimate is therefore well in line with existing evidence.

high overtime compensation of $100 \%$, a $0.6 \%$ change in hours worked will result in a change in average payroll per hour worked of only $0.006 \%$.

16 Taking into account the relatively weak empirical evidence in Table 8 as well as the identification problems of tax incentives for firms with a high number of establishments, we abstain from calculating quantitative estimates for the regression coefficients of Table 8 . 
An alternative explanation for a tax-driven reduction in payroll expense, without a corresponding change in the underlying real input measure (number of hours worked) or output measure (sales), is tax incidence. According to the economic and public finance literature, businesses may impose the local business tax burden on their employees by reducing gross wages. While there is some empirical evidence of corresponding effects (Fuest, Peichl, \& Siegloch, 2013; Siegloch, 2014), strong empirical and theoretical arguments suggest that incidence should not be the main driver of the observed tax impact on the Payroll per hour ratio and the Payroll per sales ratio in our setting.

First, the speed of the tax-driven adjustment process of payroll expense appears too rapid to be attributable to tax incidence. We find stronger effects of current TaxD on payroll than of lagged $\operatorname{TaxD} .{ }^{17}$ Hence, an increase in the local business tax rate in one year reduces the payroll expense of that establishment in the same year. However, shifting tax burdens of the employer to the employees via a reduction in gross wages would require time, as employee contracts need to be renegotiated (Fuest et al., 2013; Siegloch, 2014). As employees have a contractual entitlement to their wage payment, it seems quite unrealistic that employees would accept a considerable reduction in their gross wage to save tax payments for their employer. By contrast, the tax avoidance strategies documented by Section 2 would allow an immediate "reduction" of payroll expense in high-tax municipalities, as they simply require a reallocation of payroll in the FA partition statement.

Second, Fuest et al. (2013) argue that due to collective rent dividing negotiations, the tax burden is particularly shifted to workers under collective wage agreements. Hence, we would expect a stronger tax effect on the Payroll per hour ratio and the Payroll per sales ratio for firms with many establishments. However, we do not observe this pattern in our results. Note that Fuest et al. (2013) perform calculations for payroll per employee and not for payroll per hours worked. Thus, their calculations might be biased by changes in the number of hours worked, as suggested by Table 7 and Table 8 of our paper.

Third, the size of the tax-induced impact on the Payroll per hour ratio appears too strong to be explained by tax incidence. Corresponding to model (5) in Table 7, a one-

17 This is demonstrated by a comparison of our baseline regression results in Table 6 (Payroll share), Table 7, and Table 8 (other dependent variables) with the corresponding results for lagged $\operatorname{Tax} D$ in Table 9 (Payroll share) and Table 12 (other dependent variables). 
percentage-point increase in the local business tax rate reduces the Payroll per hour ratio by 0.546. Calculating the tax effects for a firm with two equal pre-tax establishments (see Appendix A), the tax incidence hypothesis suggests a reduction of the hourly payroll of $2.16 \%$ resulting from a one-percentage-point increase in TaxD. In the two-establishment case, the semi-elasticity on payroll for the tax incidence hypothesis is therefore nearly twice the estimated semi-elasticity for the tax avoidance hypothesis. ${ }^{18}$ Thus, a five-percentage-point increase in the local business tax rate for establishment $i$ implies a reduction of hourly wages in the same year by $10.34 \%$. Considering the bargaining power of unions and industry councils, especially in the German industrial sector, such a strong tax incidence effect is not convincing. Furthermore, the savings from such a strong reduction in gross wages would by far exceed the increase in local business tax payments. Corresponding to our calculations in Appendix A, an increase in the local business tax burden of a corporation would lead to an after-tax reduction of wage costs by approximately $€ 7.20$. Hence, the tax incidence hypothesis suggests that the reduction in wages due to tax incidence would overcompensate for the additional tax burden on a firm by more than 7 times. ${ }^{19}$ By contrast, the tax avoidance hypothesis suggests that the maximum tax saving should be much smaller than the additional burden resulting from an increase in TaxD by one percentage point. For example, if we assume an ex-ante $\operatorname{Tax}_{i}$ of $3 \%$ (approximately twice the average positive $\operatorname{Tax} D$, see Tables 4 and 5), an ex-ante even distribution of payroll between two establishments, and an increase of $\tau_{\mathrm{i}}$ in establishment $i$ by one percentage point, the tax saving from payroll shifting would be less than $5 \%$ of the additional tax burden. The reason is that an increase in $\tau_{\mathrm{i}}$ of one percentage point increases the tax burden on approximately $50 \%$ of the profits of the firm (approximately

18 The reason is the relative nature of the Payroll per hour ratio. Under the tax avoidance hypothesis, the tax impact on this variable is driven not only by reduced payroll at establishment $i$ but also by an increase in payroll at establishment $j$. By contrast, the incidence hypothesis implies that the payroll at the establishment $j$ will not be affected by an increase in the tax rate facing establishment $i$. Hence, there must be a stronger tax effect on the payroll expense at establishment $i$.

19

This is primarily driven by the fact that the average ratio between the payroll expense and the tax base of the local business tax (an adjusted pre-tax profit) from 1997 to 2008 was approximately 4.08 in the German manufacturing industry. For this calculation, we use representative balance sheet data for the manufacturing sector reported in the statistical special publication 6 (German: Statistische Sonderveröffentlichung 6) of the German Federal Bank. Hence, if the tax burden on profit increases by one percentage point, the required reduction in the wage payment would clearly be less than one percent, as aggregate wages are much higher than the assessment base of the German local business tax. 
$50 \%$ share of establishment $i$ ), whereas benefits from profit shifting are only relevant for the fraction of shifted profits (approximately 5\%).

[Table 8 about here]

In line with our assumption that we have a more effective identification strategy for our small-group sample, we find a smaller number of significant tax effects on measures of factor allocation and tax avoidance for the full sample (Table 8). Notwithstanding, the general implications of these regressions are largely the same as the results presented in Table 7. We obtain negative and significant TaxD-coefficients for the Hours per employee ratio (as the measure of real labour input) and the Payroll per sales ratio (as the measure of tax avoidance). By contrast, we do not find a significant effect for Investment share. Hence, we cannot observe an FA spillover effect on capital stock for the large-group sample in comparison to the small-group sample.

\subsection{Robustness checks}

We estimate several additional models to assess the robustness of our findings. Robustness checks are calculated for Payroll share (Table 9) and for the variables measuring FA effects for factor allocation and tax avoidance (Table 10, Table 11, Table 12). In these regressions, we consider the small-group sample (panel A) and the full sample (panel B). For simplicity, we concentrate on the main variables of interest and do not report results for control variables. We report four types of robustness checks.

First, as already discussed in Section 4, precise shifting incentives are notoriously difficult to capture for firms with three or more establishments (Heckemeyer \& Overesch 2013). In our baseline model, we model the tax incentive at the establishment level as the difference between the establishment's local business tax rate and the unweighted average tax rate of the other establishments of the same firm. While we know that firms have incentives to shift payroll out of (into) establishments with the highest (lowest) local business tax rates, the case is considerably more complicated for establishments facing intermediate levels of the tax rate (between the minimum and maximum tax rates).

Consider a firm with three establishments, A, B, C, and local business tax rates of $\mathrm{A}=10 \%, \mathrm{~B}=14 \%$, and $\mathrm{C}=20 \%$. In our standard setting, the tax incentive of establishment B is measured as $14 \%-(10 \%+20 \%) / 2=-1 \%$. Thus, considering shifting incentives from both $\mathrm{B}$ to $\mathrm{A}$ and from $\mathrm{C}$ to $\mathrm{B}$, there is a positive but small aggregate incentive to shift payroll into establishment $\mathrm{B}(\operatorname{Tax} D=-1 \%<0)$. An implicit 
assumption of our measure for the tax rate differential is that the firm considers all shifting incentives between the three establishments at the same time. In reality, this might be confounded by the complexity of tax avoidance practices, tax avoidance costs and legal and factual frictions of tax planning.

As an alternative, one might argue that the firm concentrates in each case on the largest tax rate difference compared to different establishments. In our example, the difference of local business tax rates of the establishments $\mathrm{A}$ and $\mathrm{C}$ is $10 \%$. Thus, the firm will save $0.1 €$ of local business taxes for each $1 €$ of relocated profits from establishment $\mathrm{C}$ to establishment A. In case of establishment $\mathrm{B}$, the maximum absolute tax rate difference from the other establishments is $-6 \%$ in relation to establishment $\mathrm{C}$ (instead of $+4 \%$ in relation to establishment $A$ ). Thus, if we assume that the firm will focus on the largest tax avoidance opportunity for each establishment, payroll would be shifted from $\mathrm{C}$ to $\mathrm{B}$ (tax rate difference of $-6 \%$ ). To account for this alternative theory of tax avoidance behaviour (focus on the largest shifting incentive for each establishment), we define a new measure, TaxMaxD.

$\operatorname{TaxMax} D_{i t}=\tau_{i t}-\underset{\tau_{j t}}{\arg \max }\left(\left|\tau_{i t}-\tau_{j t}\right|\right), j \neq i$

Subindex $i$ refers to the considered establishment, whereas subindex $j$ refers to the other establishments of the same firm. TaxMaxD is defined as the tax benefit of shifting $1 €$ from establishment $i$ to the establishment with the largest tax rate difference compared to $i$ (either the minimum or the maximum tax rate of all establishments of a firm). Therefore, TaxMaxD accounts for incentives to shift payroll into and out of establishments. If TaxMaxD is negative for an establishment, this shows that the strongest incentive supports shifting profits into the establishment. In contrast to $\operatorname{TaxD}$, TaxMaxD does not account for all shifting opportunities but focuses on the shifting channel with the greatest tax savings.

This can be documented by our example (three establishments with tax rates of $\mathrm{A}=10 \%, \mathrm{~B}=14 \%$, and $\mathrm{C}=20 \%$ ). The resulting tax incentives are $\mathrm{A}=-10 \%, \mathrm{~B}=-6 \%$, and $\mathrm{C}=10 \%$. Thus, payroll is shifted from $\mathrm{C}$ (positive shifting incentive) to $\mathrm{A}$ and $\mathrm{B}$ (both negative shifting incentives). If we change the local business tax rate of $\mathrm{B}$ to $17 \%$ (with $\mathrm{A}=10 \%, \mathrm{C}=20 \%$ ), the tax incentives change fundamentally for establishment $\mathrm{B}$. Now, the absolute difference between B and C (3\%) becomes smaller than the absolute difference between $\mathrm{A}$ and $\mathrm{B}(7 \%)$. We obtain the following tax rate differentials: $\mathrm{A}=$ - 
$10 \%, \mathrm{~B}=7 \%$, and $\mathrm{C}=10 \%$. Thus, the tax incentive implies that payroll is shifted from $\mathrm{C}$ and $\mathrm{B}$ (both positive shifting incentives) to A (negative shifting incentive).

We rerun our main regressions with $\operatorname{TaxMaxD}$ instead of $\operatorname{Tax} D$. The results are documented in Table 9, Model (1) and (2) (Payroll share) and Table 10 (other dependent variables). We generally obtain smaller regression coefficients and lower significance levels. The positive and significant coefficient for Sales share in the full sample (with the largest problems of measurement error) is not very convincing from a theoretical perspective. We conclude that TaxMaxD appears to be more strongly affected by measurement error than TaxD. Nevertheless, the results obtained using TaxMaxD are widely in line with our baseline estimates. Thus, we find evidence for reallocation of labour input at the intensive margin and tax avoidance practices and no significant evidence for reallocation of employees.

[Table 9 about here]

[Table 10 about here]

Second, we test if our model is robust regarding the exclusion of establishment controls. In the main specification, we include twice-lagged establishment controls (typically Sales share $_{t-2}$ and Investment share ${ }_{t-2}$ ) to account for changes and trends in the economic activity of an establishment over time (e.g., establishment growth). We generally use twice-lagged variables to avoid any endogeneity with the (lagged) tax rate differential $\operatorname{Tax}_{t}\left(\operatorname{Tax} D_{t-1}\right)$. To test the robustness of our baseline model, we exclude these control variables. The revised model can be written as

$Y_{i t}=\beta_{0}+\beta_{1} \cdot \operatorname{Tax} D_{i t}+\delta \cdot D_{i t}+\lambda_{t}+\alpha_{i}+u_{i t}$.

Estimating this alternative specification, we obtain regression results nearly identical to those of our baseline specification (Table 9, Models (3) and (4); Table 11). Thus, our model specification appears to be robust with regard to the inclusion of twice-lagged control variables accounting for establishment size. In addition, the very high values of adjusted $\mathrm{R}^{2}$ in the robustness check suggest that the explanatory power of our baseline specification stems mainly from the establishment of fixed effects. Thus, the establishment of fixed effects alone can be regarded as a very powerful control variable.

[Table 11 about here]

Third, we test whether the dynamic structure is estimated correctly. It may be argued that a change in tax rates has a generally delayed effect for all variables (e.g., Payroll 
share). In addition, one may argue that spillover effects are not delayed by one year. Thus, we consider once-lagged values of TaxD for Payroll share and all other dependent variables for which current $\operatorname{Tax} D$ is used in the standard regressions. By contrast, we consider current $\operatorname{Tax} D$ instead of lagged TaxD for Sales share and Investment share. The estimated effects (Table 9, Models (5) and (6), Table 12) are generally smaller and less significant than those of our standard models. This is particularly the case for Investment share. Therefore, our standard regression models appear to better consider the temporal dynamics than the robustness test.

[Table 12 about here]

Our regression results in Section 5.2 provide estimates for the impact of current (lagged) tax rate differentials on current payroll, sales and investment. However, if firms need some time to adjust investments or the number of employees, these results may underestimate the long-run impact of the German FA system on business activity. To acquire a more detailed picture of long-run effects, we use the modelling approach described by Wooldridge (2012, p. 346). In this model, the impact of lagged variables can be decomposed into the average long-run effect and additional short-run effects of lagged parameters. In the following, we assume that the current $\operatorname{Tax} D_{t}$ and two lags, $\operatorname{Tax} D_{t-1}, \operatorname{Tax} D_{t-2}$, will affect the dependent variable (for this approach, see, e.g., Blaufus, Hechtner, \& Möhlmann, 2017). Assuming that all lags affect the dependent variable and following regression (3), we can estimate the model

$Y_{i t}=\beta_{0}+\beta_{1} \cdot \operatorname{Tax}_{i t}+\beta_{2} \cdot \operatorname{Tax} D_{i t-1}+\beta_{3} \cdot \operatorname{Tax} D_{i t-2}+\delta \cdot D_{i t}+\lambda_{t}+\alpha_{i}+u_{i t}$.

In this model, the long-run effect can be defined by $\theta=\beta_{1}+\beta_{2}+\beta_{3}$. Substituting $\beta_{1}$ in Equation (4) by $\theta-\beta_{2}-\beta_{3}$ and rearranging terms, we obtain

$$
Y_{i t}=\beta_{0}+\theta \cdot \operatorname{Tax} D_{i t}+\beta_{2} \cdot\left(\operatorname{Tax} D_{i t-1}-\operatorname{Tax}_{i t}\right)+\beta_{3} \cdot\left(\operatorname{Tax} D_{i t-2}-\operatorname{Tax} D_{i t}\right)+\delta \cdot D_{i t}+\lambda_{t}+\alpha_{i}+u_{i t}
$$

Thus, we may use Equation (5) to identify the long-run impact of up to two lagged values of the tax differential on our dependent variables. As we assume a once-lagged tax impact on Sales share and Investment share, we adjust the model for these dependent variables and consider $\operatorname{Tax}_{t-1}, \operatorname{Tax}_{t-2}$, and $\operatorname{Tax} D_{t-3}$ instead of $\operatorname{Tax} D_{t}, \operatorname{Tax}_{t-}$ 1, and $\operatorname{Tax}_{t-2}$. In all models for long-run estimates, we abstain from including twicelagged establishment controls $E_{\mathrm{t}-2}$. As documented by our second robustness check in 5.3 (Table 9, Models (3) and (4); Table 11) including lagged establishment controls does not add much to the explanatory power of the model and leads to nearly identical 
regression results. However, including more lags of establishment controls would make the model structure more complex and - more relevantly - reduce the number of usable observations.

We report selected regression results for the small-group sample in Table 13, Panel B. In Panel A, we also repeat the short-run regression results of Table 9, Model (3) and Table 11 as a reference point for our long-run estimates. Overall, the comparison makes clear that long-run estimates do not differ significantly from short-run estimates. The only exception is Payroll share, for which we find a slightly larger coefficient of the long-run coefficient $\operatorname{Tax}_{\theta}$ compared to our standard regression coefficients $\operatorname{Tax} D_{t}$. However, considering the standard errors of both coefficient estimates, the differences are not statistically significant. In additional unreported tests, we also perform regressions corresponding to Equation (4) and consider a higher number of lagged tax differentials. The results remain largely unchanged. Overall, we conclude that the longrun effects of German FA tax incentives do not differ greatly from our baseline estimates in Section 5.1.

[Table 13]

Furthermore, we perform the following unreported additional robustness checks. Our baseline models might be biased by the fact that we only account for sales from domestic operations in the dependent variables (e.g., Sales per hour ratio) and control variables (e.g., twice-lagged Sales share). Therefore, we perform a robustness check accounting for the aggregate sum of sales from domestic operations and sales from foreign operations. Our results remain broadly unchanged. In fact, the impact of $\operatorname{Tax} D$ on the dependent variables (e.g., Payroll per sales ratio) seems to be even slightly stronger in these models. In addition, we decompose the tax rate differential into the local business tax rate of establishment $i$ and the unweighted average tax rate of the firm's opposite establishments $j \neq i$. We regress our variables of interest on the two tax rates. We find that a higher average tax rate of the opposite establishments leads to significantly higher shifting of payroll into establishment $i$. Confirming our results, we do not find a significant reaction of employee share to variations of the opposite establishments' average tax rate. Nevertheless, these estimates are less robust than our baseline specification as the decomposition might introduce errors. 


\section{Conclusion}

We address the question of how multi-establishment firms react to an FA tax regime with payroll as the exclusive FA factor. Our analysis is based on a unique panel of establishments in the German manufacturing and mining sector. Confirming previous firm-level evidence, we find that changes in the tax rate differential are significantly and negatively correlated with the allocation of payroll among constituent establishments of a firm. Therefore, firms shift payroll away from high-tax establishments to low-tax establishments to optimize overall tax burden. Our main focus is on a sample of firms with no more than three establishments (small-group sample), as the identification of FA tax incentives becomes more difficult for a larger number of establishments. Assuming that production factors are shifted between establishments, our findings for the small-group sample suggest that an increase in the tax rate differential by one percentage point reduces payroll (investment) in the high-tax establishment by $1.36 \%$ to $2.35 \%(1.04 \%)$, with a corresponding increase in the low-tax establishment. Our estimates for payroll expense fit quite well with existing evidence (Riedel, 2010).

Extending the literature, we analyse the impact of FA on the allocation of real labour input, spillover effects on investment and output, and tax avoidance strategies. We find a significant impact of the German FA regime on labour input at the intensive margin (number of hours worked per employee) but not on labour input at the extensive margin (number of employees). This outcome may be driven partially by the inflexibility of the German labour market (e.g., strong dismissal protection) and is consistent with a limited impact of the German FA tax regime on employee recruitment. For the small-group sample ( $<4$ establishments per firm), we also find evidence for spillover effects of the payroll-based German FA tax regime on gross investment in equipment and real estate. By distorting labour input, FA tax regimes may therefore indirectly distort the capital stock, which suggests that both input factors are complements rather than substitutes. Thus, our findings suggest that the German FA tax regime has a significant impact on the allocation of real production factors.

Our results are consistent with both tax avoidance and real payroll shifting, as described by the German practitioner literature and our own qualitative research. We show that the distortion of the FA factor of payroll expense significantly exceeds the distortion of the corresponding measures of real input (number of hours worked) and output (sales). Hence, firms find ways to manipulate payroll as an FA factor without adjusting real business activity. This outcome challenges the assertions in the literature that FA 
taxation may be robust to aggressive tax avoidance strategies. Introducing FA instead of SA for international taxation (e.g., in the form of a CCCTB on the European level) may therefore restrict profit shifting but also provide new tax avoidance opportunities in addition to real factor allocation. From this perspective, "fine-tuning" international tax systems (e.g., by introducing thin-capitalization rules) to narrow tax loopholes may be as relevant as the more general question of SA or FA.

Finally, we note several limitations of our paper. We provide a detailed analysis of the German local business tax FA regime for the German manufacturing and mining sector. While the manufacturing and mining sector is an important part of the German economy, our findings may not be representative of other FA tax regimes and other industries (e.g., due to different production processes and investment adjustment costs). As mentioned before, measurement of tax incentives by $\operatorname{Tax} D$ is not straightforward, which should be especially a problem for the full sample and the large-group sample. In addition, the external validity of our findings to other countries regarding the introduction of a European FA system might be debatable. Note that the German FA system relies exclusively on payroll expense as an FA factor. In addition, FA tax effects should be related to the structure of the labour market, which is more regulated in Germany than in many other countries.

Nevertheless, we are convinced that our main propositions on FA tax effects on factor allocation and tax avoidance should also be interesting in a broader context. That holds especially for our innovative findings on tax avoidance. While specific avoidance practices strongly depend on tax regulations, a full prohibition of tax avoidance practices is difficult to imagine. Corresponding to our research, that general proposition also holds for FA tax schemes. Considering the introduction of an FA-based tax system in the European Union, tax avoidance might be even more relevant than in the case of Germany. The reason is that differences in national tax rules and administrative practices typically provide more opportunities for tax avoidance. Considering, for example, the Luxembourg leaks scandal, it remains questionable whether coordinating national tax policies will actually work well in practice. While most of our results hold for the full sample and for the small-group sample, we find FA spillover effects only for the small-group sample. This lack of significant evidence might result from a more difficult identification of tax effects for large-group entities. Nevertheless, we cannot exclude the possibility that FA spillover effects are relevant only for firms with a 
limited number of establishments. Concluding, further empirical research on these issues (e.g., for other countries or industries) would be most welcome.

\section{Appendix A}

In this appendix, we briefly explain our approach to calculate the tax impact on payroll expense. As we exclusively use relative measures as dependent variables, our coefficient estimates cannot be directly interpreted as semi-elasticities. Using information from Table 4 and Table 5 as well as additional statistical data, we recalculate our estimates to provide corresponding quantitative information. As a starting point, we assume a firm with two (for the small-group sample, 2.21 establishments on average) or three (for the full sample, 3.12 establishments on average) identical establishments. Note that most firms in our data are two-establishment or three-establishment firms. Parameter specifications for the establishments are based on mean values of our descriptive statistics. Hence, for the full sample, we initially assume that all establishments generate sales of $€ 38.9$ million and have payroll expense of $€ 8.1$ million (both in 2005 prices).

In a second step, we calibrate the change in the payroll expense (or another relevant variable) that would be necessary to obtain the estimated change in the dependent variable (e.g., Payroll share or Payroll per sales ratio). In so doing, we assume that payroll expense and (respectively other dependent variables) are reallocated from hightax to low-tax establishments. Hence, a higher tax rate in one establishment reduces payroll in that establishment and increases payroll in the other establishments of the firm without an effect of $\operatorname{Tax} D$ on the aggregate sum of payroll. For simplicity, we assume that the production factors are evenly shifted to all other establishments of the same firm. For the calculation of the tax impact on our "ratio" measures (Hours per employee ratio, Payroll per hour ratio, Payroll per sales ratio), we assume in our calculations that the denominator of the corresponding ratio (e.g., the number of employees in the Hours per employee ratio) remains unchanged.

In an alternative setting, we also calculate the size of tax effects on the Payroll per hour ratio if the tax incidence hypothesis were true. Under this assumption, a change in the Payroll per hour ratio is not driven by a shifting of payroll from one establishment to another but by a reduced wage rate at one establishment at the expense of the employees of that establishment. Compared to the tax avoidance hypothesis, the tax incidence hypothesis requires a stronger tax impact on payroll at establishment $i$ to generate the 
same effect on the Payroll per hour ratio, defined as

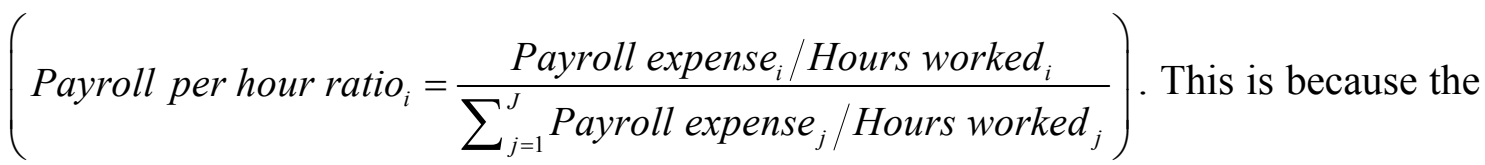

Payroll per hour ratio is not only driven by tax effects in establishment $i$ but also by tax effects in other establishments, which are assumed to be zero under the tax incidence hypothesis. Thus, if we assume a firm with two (three) establishments, the tax impact becomes twice (triple) as high as in the case of the shifting hypothesis.

With regard to the tax incidence hypothesis, we also compare the burden of an increased tax rate on firm profits with the expected reduction in after-tax wage costs. To calculate the additional burden resulting from a one-percentage-point increase in the German local business tax, we account for the deductibility of the German local business tax as a business expense before tax year 2008. The corporate income tax is assumed to be $25 \%$, the solidarity surcharge $5.5 \%$ and the local business tax multiplier 4.5 . To calculate the net benefit of a reduction in wage costs, we consider the deductibility of wages for tax purposes. We also account for differences between the assessment base of the German local business tax (adjusted pre-tax profit) and the wage costs of the firm. Thus, we assume that $25 \%$ of interest charges are non-deductible interest expenses and therefore increase the tax base of the German local business tax.

Corresponding to representative balance sheet information for the German manufacturing sector from 1997 to $2008,{ }^{20}$ wage costs are on average approximately 4.08 times higher than the tax base of the German local business tax. Hence, reducing wage costs by one percent would generate much higher savings than reducing the assessment base by one percent. Considering the deductibility of the local business tax as a business expense, a one-percentage-point increase in the local business tax rate reduces profit by $0.79 \%$, while the corresponding reduction in wage costs increases profit by $5.67 \%$.

20 We use representative balance sheet data for the manufacturing sector reported in the statistical special publication 6 (German: Statistische Sonderveröffentlichung 6) of the German Federal Bank (http://www.bundesbank.de/Navigation/DE/Statistiken/Unternehmen_und_private_Haushalte/Unterne hmens abschluesse/Tabellen/tabellen.html). 


\section{References}

Altshuler, R., \& Grubert, H. (2010). Formula apportionment: Is it better than the current system and are there better alternatives? National Tax Journal, 63, 1145-1184. doi:10.17310/ntj.2010.4S.13

Anand, B. N., \& Sensing, R. (2000). The weighting game: Formula apportionment as an instrument of public policy. National Tax Journal, 53, 183-200. doi:10.17310/ntj.2000.2.01

Baltagi, B. H. (2013). Econometric analysis of panel data (5th ed.). Hoboken, NJ: Wiley.

Becker, J., \& Fuest, C. (2010). Tax enforcement and tax havens under formula apportionment. International Tax and Public Finance, 17, 217-235. doi:10.1007/s10797-009-9121-4

Blaufus, K., Hechtner, F., \& Möhlmann, A. (2017). The effect of tax preparation expenses for employees: Evidence from Germany. Contemporary Accounting Research, 34, 525-554.

Buettner, T., Riedel, N., \& Runkel, M. (2011). Strategic consolidation under formula apportionment. National Tax Journal, 64, 225-254. doi:10.17310/ntj.2011.2.01

Clausing, K. A. (2013). Who pays the corporate tax in a global economy? National Tax Journal, 66, 151-184. doi:10.17310/ntj.2013.1.06

Clausing, K. A. (2016). The U.S. state experience under formulary apportionment: Are there lessons for international reform? National Tax Journal, 69, 353-386. doi:10.17310/ntj.2016.2.04

Clausing, K. A., \& Lahav, Y. (2011). Corporate tax payments under formulary apportionment: Evidence from the financial reports of 50 major U.S. multinational firms. Journal of International Accounting, Auditing and Taxation, 20,97-105. doi:10.1016/j.intaccaudtax.2011.06.004

Destatis. (2015). National accounts: Gross value added by industries. Retrieved September 23, 2015, from https://www.destatis.de/EN/FactsFigures/ NationalEconomyEnvironment/NationalAccounts/DomesticProduct/Tables/ GrossValueAddedIndustries_BWS.html

Devereux, M. P., \& Loretz, S. (2008). The effects of EU formula apportionment on corporate tax revenues. Fiscal Studies, 29, 1-33. doi:10.1111/j.14755890.2008.00067.x 
Dharmapala, D. (2014). What do we know about base erosion and profit shifting? A review of the empirical literature. Fiscal Studies, 35, 421-448. doi:10.1111/j.1475-5890.2014.12037.x

Dietrich, M., \& Krakowiak, M. (2009). Deutschland - ein Steuerparadies für Kapitalgesellschaften? Optimierungspotenzial der Gewerbesteuerlast am Beispiel einer Kapitalgesellschaft mit Betriebsstätten in mehreren Gemeinden [Optimizing the local business tax burden for corporations with several establishments]. Deutsches Steuerrecht, 47, 661-666.

Feld, L. P., \& Heckemeyer, J. H. (2011). FDI and taxation: A meta-study. Journal of Economic Surveys, 25, 233-272. doi:10.1111/j.1467-6419.2010.00674.x.

Forsyth, A. (2009). Protection against economic dismissals: Australian law compared with five other OECD countries. Journal of Industrial Relations, 51, 723-731. doi:10.1177/0022185609346204

Fuest, C., Peichl, A., \& Siegloch, S. (2013). Do higher corporate taxes reduce wages? Micro evidence from Germany (IZA Discussion Paper 7390). Bonn, Germany: Institute for the Study of Labor.

German Council of Economic Experts. (2011). Verantwortung für Europa Wahrnehmen: Jahresgutachten 2011/12 [Taking responsibility for Europe: Annual report 2011/12]. Berlin, Germany: German Council of Economic Experts.

Goolsbee, A., \& Maydew, E. L. (2000). Coveting thy neighbor's manufacturing: The dilemma of state income apportionment. Journal of Public Economics, 75, 125143. doi:10.1016/S0047-2727(99)00036-5

Gordon, R., \& Wilson, J. D. (1986). An examination of multijurisdictional corporate income taxation under formula apportionment. Econometrica, 54, 1357-1373. doi: $10.2307 / 1914303$

Gresik, T. A. (2010). Formula apportionment vs. separate accounting: A private information perspective. European Economic Review, 54, 133-149. doi:10.1016/j.euroecorev.2009.06.008

Gupta, S., \& Hofmann, M. A. (2003). The effect of state income tax apportionment and tax incentives on new capital expenditures. Journal of the American Taxation Association, 25, 1-25. doi:10.2308/jata.2003.25.s-1.1

Gupta, S., \& Mills, L. F. (2002). Corporate multistate tax planning: Benefits of multiple jurisdictions. Journal of Accounting and Economics, 33, 117-139. doi:10.1016/S0165-4101(01)00045-3 
Hanlon, M., \& Heitzman, S. (2010). A review of tax research. Journal of Accounting and Economics, 50, 127-178. doi:10.1016/j.jacceco.2010.09.002

Heckemeyer, J. \& Overesch, M. (2013). Multinationals' Profit Response to Tax Differentials: Effect Size and Shifting Channels, ZEW Discussion Paper No. 13045

Hines, J. R. Jr. (2010). Income misattribution under formula apportionment. European Economic Review, 54, 108-120. doi:10.1016/j.euroecorev.2009.08.011

Klassen, K. J., \& Shackelford, D. A. (1998). State and provincial corporate tax planning: Income shifting and sales apportionment factor management. Journal of Accounting and Economics, 25, 385-406. doi:10.1016/S0165-4101(98)000287

Lightner, T. (1999). The effect of the formulary apportionment system on state-level economic development and multijurisdictional tax planning. Journal of the American Taxation Association, 21, 42-57. doi:10.2308/jata.1999.21.s-1.42

Malchin, A., \& Voshage, R. (2009). Official firm data for Germany. Schmollers Jahrbuch, 129, 501-513. doi:10.3790/schm.129.3.501

Martini, J. T., Niemann, R., \& Simons, D. (2012). Transfer pricing or formula apportionment? Tax-induced distortions of multinationals' investment and production decisions. Contemporary Accounting Research, 29, 1060-1086. doi:10.1111/j.1911-3846.2012.01140.x

McLure, C. E. Jr. (1981). The elusive incidence of the corporate income tax: The state case. Public Finance Quarterly, 9, 395-413. doi:10.1177/109114218100900402

Nickell, S. (1981). Biases in dynamic models with fixed effects. Econometrica, 49, 1417-1426. doi:10.2307/1911408

Nielsen, S. B., Raimondos-Møller, P., \& Schjelderup, G. (2010). Company taxation and tax spillovers: Separate accounting versus formula apportionment. European Economic Review, 54, 121-132. doi:10.1016/j.euroecorev.2009.06.005.

Riedel, N. (2010). The downside of formula apportionment: Evidence on factor demand distortions. International Tax and Public Finance, 17, 236-258. doi:10.1007/s10797-009-9116-1

Riedel, N., \& Runkel, M. (2007). Company tax reform with a water's edge. Journal of Public Economics, 91, 1533-1554. doi:10.1016/j.jpubeco.2006.11.001

Runkel, M., \& Schjelderup, G. (2011). The choice of apportionment factors under formula apportionment. International Economic Review, 52, 913-934. doi:10.1111/j.1468-2354.2011.00654.x 
Sá, F. (2008). Does employment protection help immigrants? Evidence from European labor markets (IZA Discussion Paper No. 3414). Bonn, Germany: Institute for the Study of Labor.

Scheffler, W. (2011). Innerstaatliche Erfolgszuordnung als Instrument der Steuerplanung [Domestic profit allocation as an instrument for tax planning]. Die Unternehmensbesteuerung, 4, 262-273.

Shackelford, D., \& Slemrod, J. (1998). The revenues consequences of using formula apportionment to calculate U.S. and foreign-source income: A firm-level analysis. International Tax and Public Finance, 5, 41-59. doi:10.1023/A:1008664408465

Siegloch, S. (2014). Employment effects of local business taxes (working paper). Mannheim, Germany: University of Mannheim. Retrieved from http://www.sole-jole.org/15415.pdf

Thomsen, M., Ullmann, R., \& Watrin, C. (2014), The impact of taxes on location decisions (working paper). Münster, Germany: University of Münster.

Urbahns, R. (2010). Optimierte Zerlegung des Gewerbesteuermessbetrags [Translated title here: Optimal apportionment of the local business tax base]. Steuer und Bilanzen, 12, 425-431.

Weiner, J. M. (1996). Estimates on how the unitary tax affects business investment. Paper presented at the A.S.S.A. Meetings. San Francisco, CA.

Wooldridge, J. M. (2012). Introductory econometrics: A Modern approach (5th ed.). Mason, OH: South-Western Cengage learning.

Yetman, R. J. (2001). Tax-motivated expense allocations by nonprofit organizations. Accounting Review, 76(3), 297-311. doi:10.2308/accr.2001.76.3.297 


\section{Figures and Tables}

Figure 1: Local business tax rates in Germany, 2008

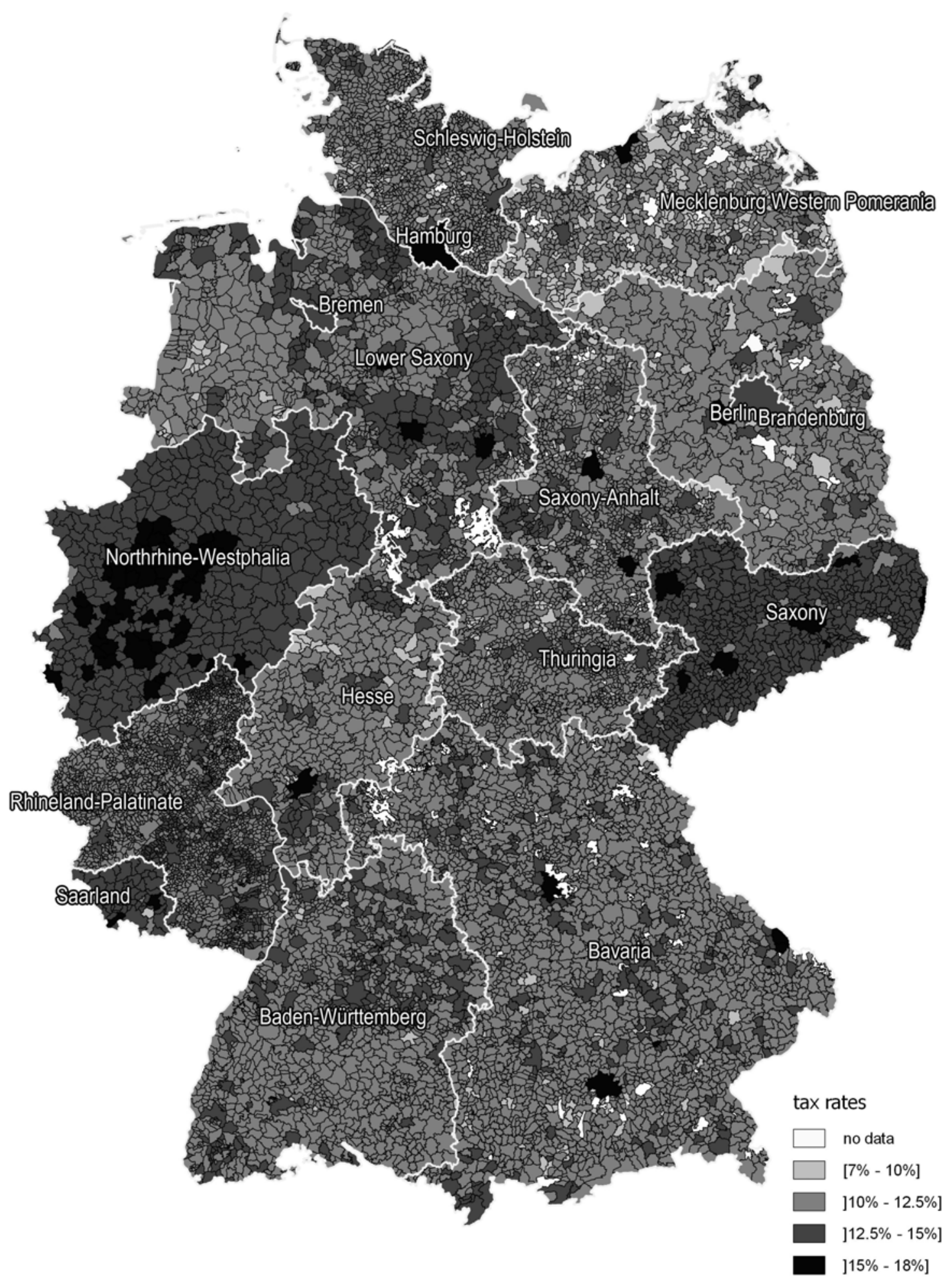


Figure 2: Number of local business tax rate changes per German municipality, 1995-2008

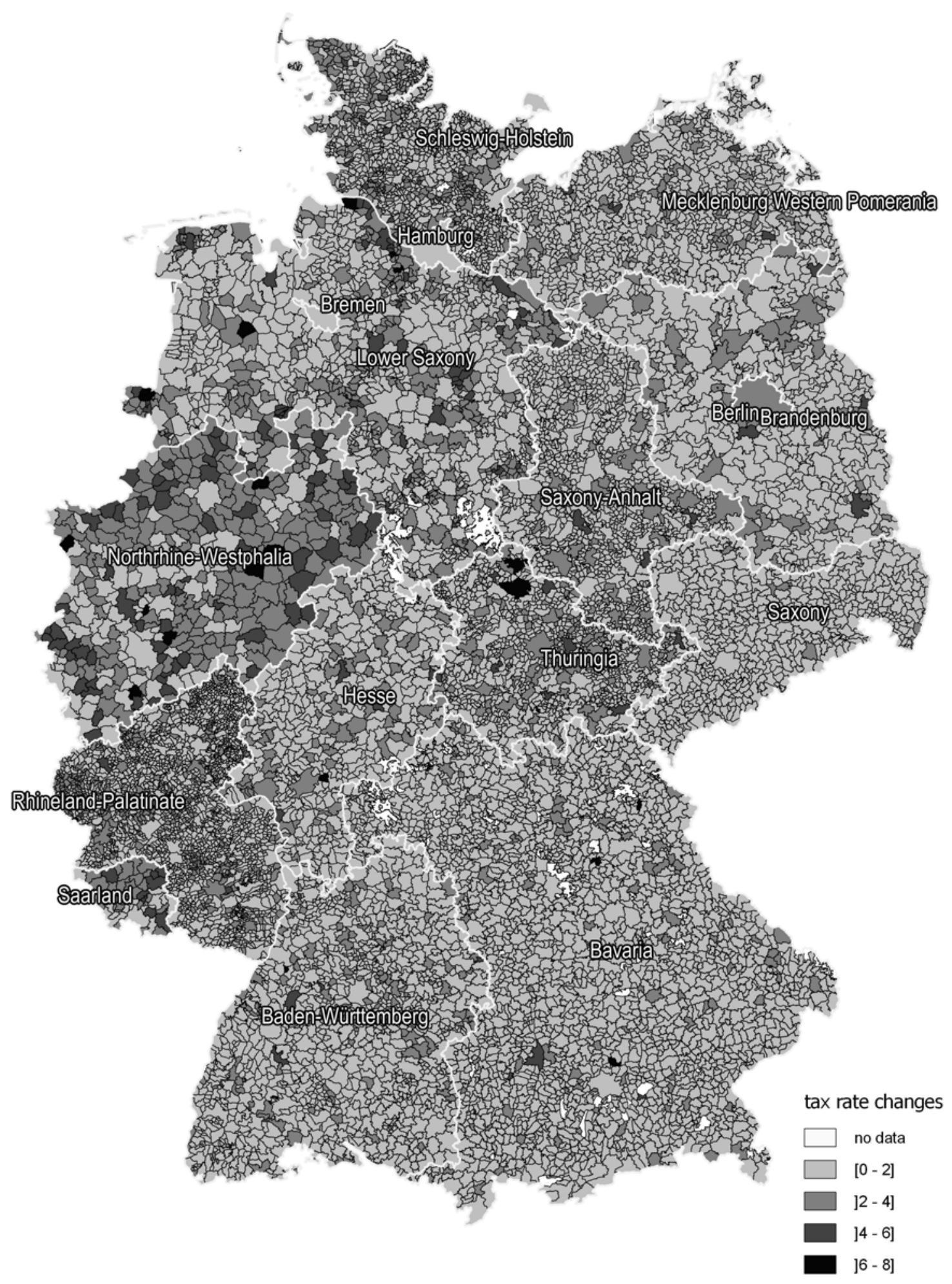


Table 1: Definitions of regression variables

Variable

Definition

Payroll share $_{\text {it }} \quad$ Payroll of establishment $i$ in year $t$ divided by the sum of payrolls of all establishments $i=0$ to $I$ in year $t$

Employee Number of employees of establishment $i$ in year $t$ divided by the sum of employees of share $_{\text {it }} \quad$ all establishments $i=0$ to $I$ in year $t$

Hours per Average hours worked per employee in establishment $i$ and year $t$ divided by the sum employee ratio $_{\text {it }} \quad$ of average hours worked per employee across all establishments $i=0$ to $I$ in year $t$

Sales share $_{\text {it }} \quad$ Sales of establishment $i$ in year $t$ divided by the total sales of all establishments $i=0$ to $I$ in year $t$

Investment Investment in fixed assets in establishment $i$ and year $t$ divided by the sum of share $_{\text {it }} \quad$ investments in fixed assets across all establishments $i=0$ to $I$ in year $t$

Payroll per hour Average payroll per number of hours worked in establishment $i$ and year $t$ divided by ratio $_{\text {it }}$ the sum of average payroll per number of hours worked across all establishments $i=0$ to $I$ in year $t$

Payroll per $\quad$ Average payroll per sales in establishment $i$ and year $t$ divided by the sum of average sales ratio $_{\text {it }} \quad$ payroll per sales across all establishments $i=0$ to $I$ in year $t$

$\operatorname{TaxD}_{\mathrm{it}} \quad$ Difference between tax rate of establishment $i$ in year $t$ and the unweighted average tax rate of all other establishments in year $t$

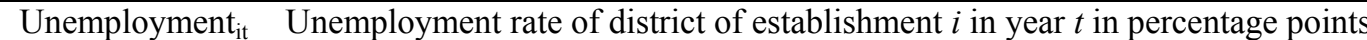

GDP per capita it $_{\text {Natural logarithm of gross domestic product per capita of district of establishment } i \text { in }}$ year $t$

Population $_{\mathrm{it}} \quad$ Natural logarithm of the population of the district of establishment $i$ in year $t$ 
Table 2: Number of firms and establishments per year

Panel A: Full sample

\begin{tabular}{crrrrr}
\hline \hline & & & \multicolumn{3}{c}{ Establishments per firm } \\
\cline { 3 - 6 } Year & Firms & Establishments & Mean & Median & Std. Dev. \\
\hline 1997 & 2,250 & 6,974 & 3.09 & 2.00 & 4.12 \\
1998 & 2,449 & 7,779 & 3.18 & 2.00 & 6.80 \\
1999 & 2,345 & 7,259 & 3.09 & 2.00 & 3.94 \\
2000 & 2,534 & 7,835 & 3.09 & 2.00 & 3.51 \\
2001 & 2,487 & 8,025 & 3.22 & 2.00 & 7.10 \\
2002 & 2,552 & 7,989 & 3.13 & 2.00 & 3.68 \\
2003 & 2,541 & 8,075 & 3.18 & 2.00 & 3.75 \\
2004 & 2,667 & 8,528 & 3.20 & 2.00 & 3.77 \\
2005 & 2,792 & 8,753 & 3.13 & 2.00 & 4.20 \\
2006 & 2,882 & 9,059 & 3.14 & 2.00 & 4.47 \\
2007 & 1,740 & 5,118 & 2.94 & 2.00 & 3.56 \\
2008 & 1,778 & 5,284 & 2.97 & 2.00 & 4.47 \\
\hline Sum & 29,017 & 90,678 & 3.12 & & \\
\hline \hline Panel B: Small-group sample & & & & \\
\hline \hline & & & & & \\
\cline { 4 - 6 } Year & Firms & Establishments & Mean & Median & Std. Dev. \\
\hline 1997 & 1,858 & 4,095 & 2.20 & 2.00 & 0.40 \\
1998 & 2,015 & 4,427 & 2.19 & 2.00 & 0.39 \\
1999 & 1,935 & 4,276 & 2.20 & 2.00 & 0.40 \\
2000 & 2,073 & 4,598 & 2.21 & 2.00 & 0.41 \\
2001 & 2,042 & 4,495 & 2.20 & 2.00 & 0.40 \\
2002 & 2,068 & 4,566 & 2.20 & 2.00 & 0.40 \\
2003 & 2,055 & 4,544 & 2.21 & 2.00 & 0.40 \\
2004 & 2,153 & 4,740 & 2.20 & 2.00 & 0.40 \\
2005 & 2,294 & 5,055 & 2.20 & 2.00 & 0.40 \\
2006 & 2,370 & 5,198 & 2.19 & 2.00 & 0.39 \\
2007 & 1,461 & 3,229 & 2.20 & 2.00 & 0.40 \\
2008 & 1,495 & 3,319 & 2.21 & 2.00 & 0.41 \\
\hline Sum & 23,819 & 52,542 & 2.21 & & \\
\hline \hline & & & & & \\
\hline
\end{tabular}

Notes: AFiD panel industrial units of the manufacturing industry. 
Table 3: Development of local business tax rates over time

Panel A: Local business tax rates per year

\begin{tabular}{|c|c|c|c|c|c|c|}
\hline Year & $\mathrm{N}$ & Mean & Median & Std. Dev. & & \\
\hline 1997 & 7,029 & 0.1542 & 0.1507 & 0.0181 & & \\
\hline 1998 & 7,833 & 0.1544 & 0.1489 & 0.0186 & & \\
\hline 1999 & 7,306 & 0.1554 & 0.1525 & 0.0182 & & \\
\hline 2000 & 7,929 & 0.1548 & 0.1525 & 0.0182 & & \\
\hline 2001 & 7,921 & 0.1550 & 0.1525 & 0.0180 & & \\
\hline 2002 & 8,058 & 0.1552 & 0.1525 & 0.0180 & & \\
\hline 2003 & 8,030 & 0.1561 & 0.1525 & 0.0183 & & \\
\hline 2004 & 8,473 & 0.1569 & 0.1525 & 0.0184 & & \\
\hline 2005 & 8,705 & 0.1572 & 0.1525 & 0.0185 & & \\
\hline 2006 & 9,055 & 0.1576 & 0.1525 & 0.0184 & & \\
\hline 2007 & 5,119 & 0.1588 & 0.1561 & 0.0182 & & \\
\hline $2008 *$ & 5,220 & 0.1327 & 0.1295 & 0.0181 & & \\
\hline Total & 90,678 & 0.1546 & 0.1525 & 0.0191 & & \\
\hline \multicolumn{7}{|c|}{ Panel B: Tax cuts and tax increases per year } \\
\hline & \multicolumn{3}{|c|}{ Increasing tax rates } & \multicolumn{3}{|c|}{ Decreasing tax rates } \\
\hline Year & $\mathrm{N}$ & Mean & Std. Dev & $\mathrm{N}$ & Mean & Std. Dev \\
\hline 1998 & 818 & 0.0068 & 0.0054 & 73 & -0.0108 & 0.0120 \\
\hline 1999 & 413 & 0.0071 & 0.0069 & 223 & -0.0044 & 0.0056 \\
\hline 2000 & 425 & 0.0055 & 0.0038 & 176 & -0.0053 & 0.0057 \\
\hline 2001 & 461 & 0.0073 & 0.0069 & 347 & -0.0051 & 0.0041 \\
\hline 2002 & 581 & 0.0072 & 0.0066 & 94 & -0.0091 & 0.0086 \\
\hline 2003 & 967 & 0.0077 & 0.0079 & 119 & -0.0064 & 0.0127 \\
\hline 2004 & 549 & 0.0066 & 0.0068 & 60 & -0.0081 & 0.0082 \\
\hline 2005 & 694 & 0.0068 & 0.0058 & 126 & -0.0068 & 0.0076 \\
\hline 2006 & 515 & 0.0063 & 0.0037 & 120 & -0.0088 & 0.0104 \\
\hline 2007 & 103 & 0.0065 & 0.0051 & 193 & -0.0073 & 0.0089 \\
\hline $2008 *$ & 0 & 0.0000 & 0.0000 & 5,220 & -0.0262 & 0.0021 \\
\hline
\end{tabular}

Notes: AFiD panel industrial units of the manufacturing industry.

*: The Business Tax Reform 2008/2009 reduced the basic rate of the local business tax. 
Table 4: Descriptive Statistics

\begin{tabular}{lcccc} 
Variable & Mean & Median & Std. Dev. & $\mathrm{N}$ \\
\hline Sales (1,000 euro) & $38,892.27$ & $6,736.57$ & $199,851.91$ & 90,678 \\
Gross investment (1,000 euro) & $3,542.40$ & 290.40 & $25,446.08$ & 90,678 \\
Payroll expense (1,000 euro) & $8,601.54$ & $1,692.95$ & $46,967.13$ & 90,678 \\
Number of employees & 318.85 & 82.08 & $1,343.55$ & 90,678 \\
Monthly hours per employee & 135.49 & 133.03 & 27.32 & 90,678 \\
\hline Local business tax rate & 0.1546 & 0.0191 & 0.1525 & 90,678 \\
TaxD (tax rate differential) & -0.0003 & 0.0000 & 0.0198 & 90,678 \\
TaxD $\geq 0$ & 0.0142 & 0.0109 & 0.0131 & 46,433 \\
TaxD < 0 & -0.0156 & -0.0121 & 0.0129 & 44,245 \\
\hline Payroll share & 0.3511 & 0.2658 & 0.2979 & 90,678 \\
Employee share & 0.3463 & 0.2598 & 0.2912 & 90,678 \\
Hours per employee ratio & 0.3440 & 0.3384 & 0.2112 & 90,678 \\
Sales share & 0.3478 & 0.3374 & 0.2353 & 90,678 \\
Investment share & 0.3491 & 0.3580 & 0.2000 & 90,678 \\
Payroll per hour ratio & 0.3468 & 0.3388 & 0.2269 & 90,678 \\
Payroll per sales ratio & 0.3282 & 0.2549 & 0.3225 & 90,678 \\
\hline Unemployment rate (district level) & 0.1054 & 0.0920 & 0.0481 & 90,678 \\
GDP per capita (district level) & 26,453 & 23,726 & 11,073 & 90,678 \\
Population (district level) & 332,160 & 198,964 & 481,340 & 90,678 \\
\hline Notes AFD pan
\end{tabular}

Notes: AFiD panel industrial units of the manufacturing industry; price-adjusted data; own calculations. 
Table 5: Descriptive statistics for subsamples

\begin{tabular}{|c|c|c|c|c|}
\hline Panel A: Small groups ( $<$ four establishments) & Mean & Median & Std. Dev. & $\mathrm{N}$ \\
\hline Sales $(1,000$ euro $)$ & $31,651.72$ & $7,349.57$ & $157,414.96$ & $\overline{52,542}$ \\
\hline Gross investments ( 1,000 euro) & $2,735.99$ & 346.06 & $19,660.29$ & 52,542 \\
\hline Payroll expense (1,000 euro) & $6,478.32$ & $1,834.66$ & $31,614.51$ & 52,542 \\
\hline Number of employees & 252.39 & 89.92 & 961.52 & 52,542 \\
\hline Monthly hours per employee & 134.35 & 131.76 & 24.76 & 52,542 \\
\hline Local business tax rate & 0.1528 & 0.0185 & 0.1489 & 52,542 \\
\hline TaxD (tax rate differential) & -0.0005 & 0.0000 & 0.0215 & 52,542 \\
\hline $\operatorname{TaxD} \geq 0$ & 0.0145 & 0.0107 & 0.0144 & 28,011 \\
\hline $\operatorname{TaxD}<0$ & -0.0176 & -0.0139 & 0.0143 & 24,531 \\
\hline Payroll share & 0.4925 & 0.4775 & 0.2893 & 52,542 \\
\hline Employee share & 0.4868 & 0.4741 & 0.2791 & 52,542 \\
\hline Hours per employee ratio & 0.4843 & 0.4905 & 0.1462 & 52,542 \\
\hline Sales share & 0.4892 & 0.3495 & 0.4727 & 52,542 \\
\hline Investment share & 0.4901 & 0.3696 & 0.4730 & 52,542 \\
\hline Payroll per hour ratio & 0.4886 & 0.4846 & 0.1760 & 52,542 \\
\hline Payroll per sales ratio & 0.4629 & 0.4536 & 0.3183 & 52,542 \\
\hline Unemployment rate (percent, district level) & 0.1018 & 0.0880 & 0.0476 & 52,542 \\
\hline GDP per capita (district level) & 25,799 & 23,619 & 10,203 & 52,542 \\
\hline Population (district level) & 315,657 & 194,169 & 455,311 & 52,542 \\
\hline Panel B: Large groups ( $\geq$ four establishments) & Mean & Median & Std. Dev. & $\mathrm{N}$ \\
\hline Sales $(1,000$ euro $)$ & $48,867.97$ & $5,609.63$ & $246,290.04$ & 38,136 \\
\hline Gross investments ( 1,000 euro) & $4,653.43$ & 211.53 & $31,700.99$ & 38,136 \\
\hline Payroll expense (1,000 euro) & $11,526.82$ & $1,384.55$ & $62,075.61$ & 38,136 \\
\hline Number of employees & 410.43 & 66.42 & $1,733.18$ & 38,136 \\
\hline Monthly hours per employee & 137.06 & 134.65 & 30.43 & 38,136 \\
\hline Local business tax rate & 0.1570 & 0.0196 & 0.1561 & 38,136 \\
\hline TaxD (tax rate differential) & -0.0002 & -0.0009 & 0.0172 & 38.136 \\
\hline $\operatorname{TaxD} \geq 0$ & 0.0138 & 0.0115 & 0.0108 & 18,422 \\
\hline $\operatorname{TaxD}<0$ & -0.0132 & -0.0108 & 0.0105 & 19,714 \\
\hline Payroll share & 0.1562 & 0.0963 & 0.1738 & 38,136 \\
\hline Employee share & 0.1527 & 0.0912 & 0.1719 & 38,136 \\
\hline Hours per employee ratio & 0.1507 & 0.1423 & 0.1100 & 38,136 \\
\hline Sales share & 0.1530 & 0.0849 & 0.1924 & 38,136 \\
\hline Investment share & 0.1548 & 0.0508 & 0.2268 & 38,136 \\
\hline Payroll per hour ratio & 0.1516 & 0.1378 & 0.1183 & 38,136 \\
\hline Payroll per sales ratio & 0.1426 & 0.0617 & 0.2199 & 38,136 \\
\hline Unemployment rate (district level) & 0.1104 & 0.0980 & 0.0484 & 38,136 \\
\hline GDP per capita (district level) & 27,352 & 23,858 & 12,113 & 38,136 \\
\hline Population (district level) & 354,896 & 202,658 & 514,190 & 38,136 \\
\hline
\end{tabular}

Notes: AFiD panel industrial units of the manufacturing industry; price-adjusted data; own calculations. 
Table 6: Results: Payroll share

\begin{tabular}{|c|c|c|c|c|c|c|}
\hline MODEL & (1) & (2) & $(3)$ & $(4)$ & $(5)$ & $(6)$ \\
\hline Dependent variable & $\begin{array}{l}\text { Payroll } \\
\text { share }\end{array}$ & Payroll share & $\begin{array}{l}\text { Payroll } \\
\text { share }\end{array}$ & $\begin{array}{l}\text { Payroll } \\
\text { share }\end{array}$ & $\begin{array}{l}\text { Payroll } \\
\text { share }\end{array}$ & Payroll share \\
\hline Sample & Full sample & Small groups & $\begin{array}{l}\text { Large } \\
\text { groups }\end{array}$ & Full sample & Full sample & Full sample \\
\hline $\operatorname{TaxD}_{t}$ & $\begin{array}{l}-0.427 * * \\
(0.172)\end{array}$ & $\begin{array}{l}-\mathbf{0 . 6 7 8 * * *} \\
(0.203)\end{array}$ & $\begin{array}{l}0.0140 \\
(0.189)\end{array}$ & $\begin{array}{l}-\mathbf{0 . 4 4 7 * *} \\
(0.182)\end{array}$ & $\begin{array}{l}-0.482 * * * \\
(0.178)\end{array}$ & $\begin{array}{l}-0.445 * \\
(0.245) \\
\end{array}$ \\
\hline $\operatorname{TaxD}_{t} \times$ Small group $_{t}$ & & & & $\begin{array}{l}-\mathbf{- 0 . 0 4 5 5} \\
(0.202)\end{array}$ & & \\
\hline $\operatorname{TaxD}_{t} \times$ Establishments $_{t}$ & & & & & $\begin{array}{l}-0.00464 \\
(0.00593)\end{array}$ & \\
\hline TaxD $\times$ LN $\left(\right.$ Establishments $\left._{t}\right)$ & & & & & & $\begin{array}{l}-0.136 \\
(0.130) \\
\end{array}$ \\
\hline Investment share $_{t-2}$ & $\begin{array}{l}0.0352 * * * \\
(0.00267)\end{array}$ & $\begin{array}{l}0.0272 * * * \\
(0.00290)\end{array}$ & $\begin{array}{l}0.0185 * * * \\
(0.00448)\end{array}$ & $\begin{array}{l}0.0311 * * * \\
(0.00253)\end{array}$ & $\begin{array}{l}0.0340 * * * \\
(0.00264)\end{array}$ & $\begin{array}{l}0.0273 * * * \\
(0.00245)\end{array}$ \\
\hline Sales share $_{\mathrm{t}-2}$ & $\begin{array}{l}0.107 * * * \\
(0.00603)\end{array}$ & $\begin{array}{l}0.0716 * * * \\
(0.00673)\end{array}$ & $\begin{array}{l}0.0454 * * * \\
(0.00848)\end{array}$ & $\begin{array}{l}0.0860 * * * \\
(0.00546)\end{array}$ & $\begin{array}{l}0.102 * * * \\
(0.00589)\end{array}$ & $\begin{array}{l}0.0748 * * * \\
(0.00519)\end{array}$ \\
\hline Unemployment & $\begin{array}{l}0.00318^{* * *} \\
(0.000692)\end{array}$ & $\begin{array}{l}0.00487 * * * \\
(0.000955)\end{array}$ & $\begin{array}{l}0.00168 * * \\
(0.000759)\end{array}$ & $\begin{array}{l}0.00295 * * * \\
(0.000658)\end{array}$ & $\begin{array}{l}0.00341 * * * \\
(0.000684)\end{array}$ & $\begin{array}{l}0.00331^{* * *} \\
(0.000644)\end{array}$ \\
\hline GDP per capita & $\begin{array}{l}-0.0213 * \\
(0.0112)\end{array}$ & $\begin{array}{l}-0.0313 * \\
(0.0185)\end{array}$ & $\begin{array}{l}-0.0133 \\
(0.0102)\end{array}$ & $\begin{array}{l}-0.0211 * \\
(0.0109)\end{array}$ & $\begin{array}{l}-0.0212 * \\
(0.0110)\end{array}$ & $\begin{array}{l}-0.0193 * \\
(0.0103)\end{array}$ \\
\hline Population & $\begin{array}{l}-0.00660 \\
(0.00852)\end{array}$ & $\begin{array}{l}-0.0128 \\
(0.0109) \\
\end{array}$ & $\begin{array}{l}-0.000692 \\
(0.0120) \\
\end{array}$ & $\begin{array}{l}-0.00390 \\
(0.00825) \\
\end{array}$ & $\begin{array}{l}-0.00571 \\
(0.00815) \\
\end{array}$ & $\begin{array}{l}-0.00255 \\
(0.00785) \\
\end{array}$ \\
\hline Small group $_{t}$ & & & & $\begin{array}{l}0.150 * * * \\
0.00510\end{array}$ & & \\
\hline Establishments $_{t}$ & & & & & $\begin{array}{l}- \\
0.00232 * * * \\
0.000135\end{array}$ & \\
\hline LN(Establishments $\left.\mathrm{t}_{\mathrm{t}}\right)$ & & & & & & $\begin{array}{l}-0.144 * * * \\
0.00371\end{array}$ \\
\hline Year FE & Yes & Yes & Yes & Yes & Yes & Yes \\
\hline Establishment FE & Yes & Yes & Yes & Yes & Yes & Yes \\
\hline Observations & 90,678 & 52,542 & 38,136 & 90,678 & 90,678 & 90,678 \\
\hline Within $\mathrm{R}^{2}$ & 0.0451 & 0.0248 & 0.0206 & 0.127 & 0.0661 & 0.181 \\
\hline Adjusted $\mathrm{R}^{2}$ & 0.901 & 0.894 & 0.869 & 0.910 & 0.903 & 0.915 \\
\hline $\begin{array}{l}\text { Notes: Regressions are calcul } \\
\text { standard errors, which have be } \\
\text { and * indicate statistical signif } \\
\text { independent variables is provid }\end{array}$ & $\begin{array}{l}\text { ted by OLS } \\
\text { n clustered a } \\
\text { cance at the } \\
\text { d by Table } 1\end{array}$ & $\begin{array}{l}\text { ith establish } \\
\text { the establishr } \\
0,5 \% \text {, and } 1\end{array}$ & $\begin{array}{l}\text { nt fixed ef } \\
\text { at level, ar } \\
\text { levels, re }\end{array}$ & $\begin{array}{l}\text { ts and year } \\
\text { cumented i } \\
\text { ctively. A d }\end{array}$ & $\begin{array}{l}\text { xed effects. H } \\
\text { oarentheses. T } \\
\text { iled descriptic }\end{array}$ & $\begin{array}{l}\text { eteroscedasticity-robust } \\
\text { he superscripts } * * *, * * \text {, } \\
\text { n of the dependent and }\end{array}$ \\
\hline
\end{tabular}


Table 7: Results: Factor allocation and tax avoidance (small-group sample)

\begin{tabular}{|c|c|c|c|c|c|c|}
\hline MODEL & $(1)$ & $(2)$ & (3) & $(4)$ & $(5)$ & (6) \\
\hline $\begin{array}{l}\text { Dependent } \\
\text { variable } Y_{t}\end{array}$ & $\begin{array}{l}\text { Employee } \\
\text { share }\end{array}$ & $\begin{array}{l}\text { Hours per } \\
\text { employee ratio }\end{array}$ & Sales share & $\begin{array}{l}\text { Investment } \\
\text { share }\end{array}$ & $\begin{array}{l}\text { Payroll per } \\
\text { hour ratio }\end{array}$ & $\begin{array}{l}\text { Payroll per } \\
\text { sales ratio }\end{array}$ \\
\hline $\operatorname{TaxD}_{t}$ & $\begin{array}{l}-0.109 \\
(0.182)\end{array}$ & $\begin{array}{l}-0.634 * * * \\
(0.179)\end{array}$ & & & $\begin{array}{l}-0.546 * * * \\
(0.203)\end{array}$ & $\begin{array}{l}-1.271 * * * \\
(0.276)\end{array}$ \\
\hline $\operatorname{TaxD}_{t-1}$ & & & $\begin{array}{l}-0.0494 \\
(0.214) \\
\end{array}$ & $\begin{array}{l}-0.518 * * \\
(0.248)\end{array}$ & & \\
\hline Sales share $_{\mathrm{t}-2}$ & $\begin{array}{l}0.0867 * * * \\
(0.00583)\end{array}$ & $\begin{array}{l}0.0144 * * * \\
(0.00519)\end{array}$ & & $\begin{array}{l}0.0417 * * * \\
(0.0134)\end{array}$ & $\begin{array}{l}0.0447 * * * \\
(0.00615)\end{array}$ & $\begin{array}{l}-0.130 * * * \\
(0.0103)\end{array}$ \\
\hline Payroll share $_{\mathrm{t}-2}$ & & & $\begin{array}{l}0.117 * * * \\
(0.00958)\end{array}$ & $\begin{array}{l}0.0295 * * \\
(0.0148)\end{array}$ & & \\
\hline Year FE & Yes & Yes & Yes & Yes & Yes & Yes \\
\hline Within $\mathrm{R}^{2}$ & 0.0536 & 0.177 & 0.0276 & 0.00285 & 0.106 & 0.0206 \\
\hline Adjusted R ${ }^{2}$ & 0.946 & 0.565 & 0.907 & 0.659 & 0.516 & 0.770 \\
\hline \multicolumn{7}{|c|}{$\begin{array}{l}\text { Notes: Regressions are calculated by OLS with establishment fixed effects and year fixed effects. Heteroscedasticity- } \\
\text { robust standard errors, which have been clustered at the establishment level, are documented in parentheses. The } \\
\text { superscripts } * * *, * * \text {, and } * \text { indicate statistical significance at the } 1 \%, 5 \% \text {, and } 10 \% \text { levels, respectively. A detailed } \\
\text { description of the dependent and independent variables is provided by Table } 1 .\end{array}$} \\
\hline
\end{tabular}

Table 8: Results: Factor allocation and tax avoidance (full sample)

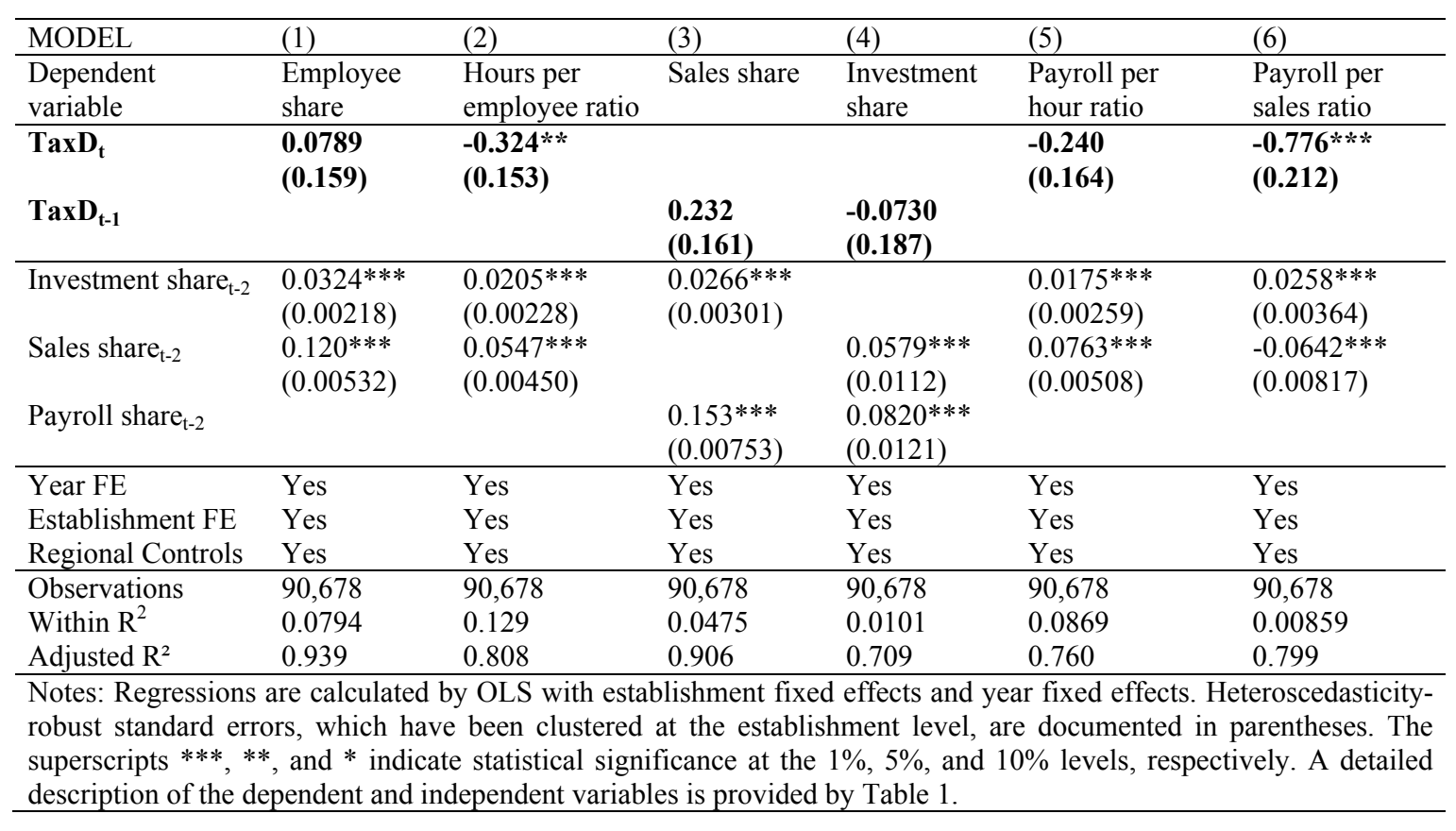


Table 9: Robustness checks: Payroll share

\begin{tabular}{|c|c|c|c|c|c|c|}
\hline MODEL & (1) & (2) & (3) & (4) & (5) & $(6)$ \\
\hline Dependent variable & Payroll share & Payroll share & Payroll share & Payroll share & Payroll share & Payroll share \\
\hline Robustness check & TaxMaxD & TaxMaxD & Controls & Controls & Timing & Timing \\
\hline Sample & Small groups & Full & Small groups & Full & Small groups & Full \\
\hline $\operatorname{TaxMaxD}_{t}$ & $\begin{array}{l}-\mathbf{- 0 . 4 4 6 * * *} \\
(0.158)\end{array}$ & $\begin{array}{l}-0.157 * * \\
(0.0674)\end{array}$ & & & & \\
\hline $\operatorname{TaxD}_{t}$ & & & $\begin{array}{l}-0.657 * * * \\
(0.212)\end{array}$ & $\begin{array}{l}-0.381 * * * \\
(0.185)\end{array}$ & & \\
\hline $\operatorname{TaxD}_{t-1}$ & & & & & $\begin{array}{l}-0.484 * * * \\
(0.164)\end{array}$ & $\begin{array}{l}-0.288 * * \\
(0.137)\end{array}$ \\
\hline Year FE & Yes & Yes & Yes & Yes & Yes & Yes \\
\hline Establishment FE & Yes & Yes & Yes & Yes & Yes & Yes \\
\hline Establishment controls & Yes & Yes & No & No & Yes & Yes \\
\hline Regional controls & Yes & Yes & Yes & Yes & Yes & Yes \\
\hline Observations & 52,542 & 90,678 & 52,542 & 90,678 & 52,542 & 90,678 \\
\hline Within $\mathrm{R}^{2}$ & 0.0243 & 0.0448 & 0.00468 & 0.00446 & 0.0242 & 0.0448 \\
\hline Adjusted $\mathrm{R}^{2}$ & 0.894 & 0.901 & 0.891 & 0.897 & 0.893 & 0.901 \\
\hline $\begin{array}{l}\text { Notes: Regressions are } \\
\text { robust standard errors } \\
\text { superscripts } * * *, * *, \\
\text { description of the depe }\end{array}$ & $\begin{array}{l}\text { lculated by } \mathrm{C} \\
\text { hich have bc } \\
* \text { indiate }\end{array}$ & $\begin{array}{l}\text { S with establ } \\
\text { clustered a } \\
\text { istical signifi } \\
\text { dent variable }\end{array}$ & ment fixed & cts and year & $\begin{array}{l}\text { ed effects. He } \\
\text { umented in } p \\
\text { evels, respecti }\end{array}$ & $\begin{array}{l}\text { roscedasticity- } \\
\text { rentheses. The } \\
\text { ely. A detailed }\end{array}$ \\
\hline
\end{tabular}

Table 10: Robustness checks: Alternative calculation of the tax rate differential

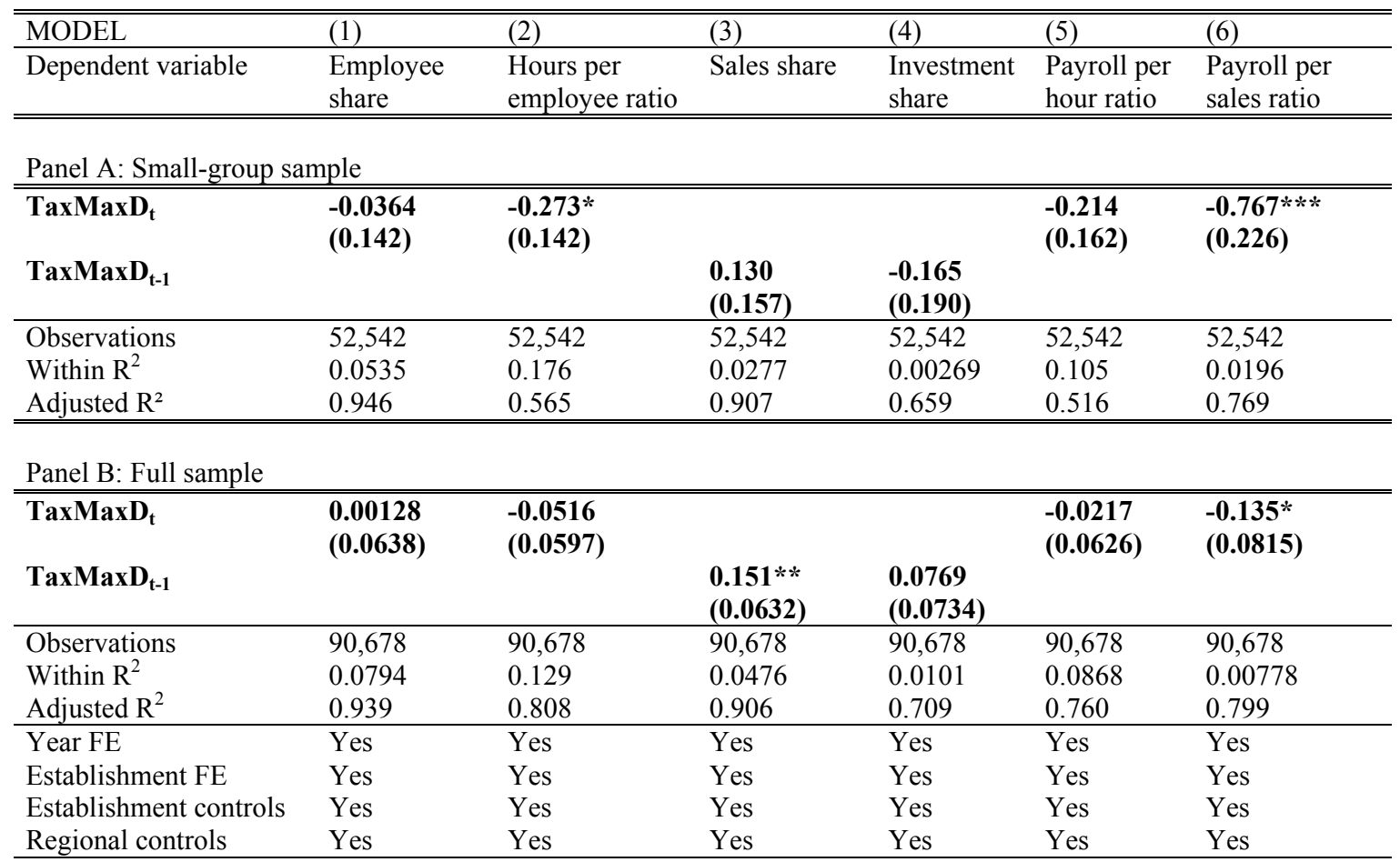

Notes: Regressions are calculated by OLS with establishment fixed effects and year fixed effects. Heteroscedasticityrobust standard errors, which have been clustered at the establishment level, are documented in parentheses. The superscripts $* * *, * *$, and $*$ indicate statistical significance at the $1 \%, 5 \%$, and $10 \%$ levels, respectively. Detailed descriptions of the dependent and independent variables are provided in Table 1. Panel A refers to the small-group sample (firms with less than 4 establishments), and Panel B refers to the full sample. 
Table 11: Robustness checks: Factor allocation and tax avoidance - without establishment controls

\begin{tabular}{|c|c|c|c|c|c|c|}
\hline MODEL & $(1)$ & $(2)$ & (3) & (4) & $(5)$ & $(6)$ \\
\hline Dependent variable & $\begin{array}{l}\text { Employee } \\
\text { share }\end{array}$ & $\begin{array}{l}\text { Hours per } \\
\text { employee ratio }\end{array}$ & Sales share & $\begin{array}{l}\text { Investment } \\
\text { share }\end{array}$ & $\begin{array}{l}\text { Payroll per } \\
\text { hour ratio }\end{array}$ & $\begin{array}{l}\text { Payroll per } \\
\text { sales ratio }\end{array}$ \\
\hline \multicolumn{7}{|c|}{ Panel A: Small-group sample } \\
\hline $\operatorname{TaxD}_{t}$ & $\begin{array}{l}-0.118 \\
(0.176)\end{array}$ & $\begin{array}{l}-0.633^{* * * *} \\
(0.178)\end{array}$ & & & $\begin{array}{l}-0.545 * * * \\
(0.204)\end{array}$ & $\begin{array}{l}-1.310 * * * \\
(0.280)\end{array}$ \\
\hline $\operatorname{TaxD}_{t-1}$ & & & $\begin{array}{c}-\mathbf{0 . 0 9 6 2} \\
(0.189) \\
\end{array}$ & $\begin{array}{l}-0.529 * * \\
(0.251)\end{array}$ & & \\
\hline Observations & 52,542 & 52,542 & 52,542 & 52,542 & 52,542 & 52,542 \\
\hline Within $\mathrm{R}^{2}$ & 0.00204 & 0.175 & 0.00153 & 0.00118 & 0.102 & 0.00654 \\
\hline Adjusted $\mathrm{R}^{2}$ & 0.943 & 0.564 & 0.905 & 0.658 & 0.514 & 0.766 \\
\hline \multicolumn{7}{|l|}{ Panel B: Full sample } \\
\hline $\operatorname{TaxD}_{t}$ & $\begin{array}{l}0.130 \\
(0.174)\end{array}$ & $\begin{array}{l}-0.300 * \\
(0.157)\end{array}$ & & & $\begin{array}{l}-\mathbf{- 0 . 2 0 8} \\
(0.170)\end{array}$ & $\begin{array}{l}-0.799 * * * \\
(0.212)\end{array}$ \\
\hline $\operatorname{TaxD}_{t-1}$ & & & $\begin{array}{l}0.237 \\
(0.176)\end{array}$ & $\begin{array}{l}-\mathbf{- 0 . 0 4 9 8} \\
\mathbf{( 0 . 1 9 8 )} \\
\end{array}$ & & \\
\hline Observations & 90,678 & 90,678 & 90,678 & 90,678 & 90,678 & 90,678 \\
\hline Within $\mathrm{R}^{2}$ & 0.00367 & 0.118 & 0.00255 & 0.00210 & 0.0751 & 0.00505 \\
\hline Adjusted $\mathrm{R}^{2}$ & 0.934 & 0.806 & 0.901 & 0.707 & 0.757 & 0.798 \\
\hline Year FE & Yes & Yes & Yes & Yes & Yes & Yes \\
\hline Establishment FE & Yes & Yes & Yes & Yes & Yes & Yes \\
\hline Establishment controls & No & No & No & No & No & No \\
\hline Regional controls & Yes & Yes & Yes & Yes & Yes & Yes \\
\hline \multicolumn{7}{|c|}{$\begin{array}{l}\text { Notes: Regressions are calculated by OLS with establishment fixed effects and year fixed effects. Heteroscedasticity- } \\
\text { robust standard errors, which have been clustered at the establishment level, are documented in parentheses. The } \\
\text { superscripts } * * *, * * \text {, and * indicate statistical significance at the } 1 \%, 5 \% \text {, and } 10 \% \text { levels, respectively. A detailed } \\
\text { description of the dependent and independent variables is provided by Table } 1 \text {. Panel A refers to the small-group } \\
\text { sample (firms with less than } 4 \text { establishments) and Panel B refers to the full sample. }\end{array}$} \\
\hline
\end{tabular}

Table 12: Robustness checks: Factor allocation and tax avoidance - timing effects

\begin{tabular}{|c|c|c|c|c|c|c|}
\hline MODEL & (1) & (2) & (3) & (4) & (5) & (6) \\
\hline Dependent variable & $\begin{array}{l}\text { Employee } \\
\text { share }\end{array}$ & $\begin{array}{l}\text { Hours per } \\
\text { employee ratio }\end{array}$ & Sales share & $\begin{array}{l}\text { Investment } \\
\text { share }\end{array}$ & $\begin{array}{l}\text { Payroll per } \\
\text { hour ratio }\end{array}$ & $\begin{array}{l}\text { Payroll per } \\
\text { sales ratio }\end{array}$ \\
\hline \multicolumn{7}{|c|}{ Panel A: Small-group sample } \\
\hline $\operatorname{TaxD}_{\mathrm{t}}$ & & & $\begin{array}{l}-0.137 \\
(0.253)\end{array}$ & $\begin{array}{l}-0.444 \\
(0.282)\end{array}$ & & \\
\hline $\operatorname{TaxD}_{\mathrm{t}-1}$ & $\begin{array}{l}0.0694 \\
(0.147)\end{array}$ & $\begin{array}{l}-0.236 \\
(0.145)\end{array}$ & & & $\begin{array}{l}-0.401 * * \\
(0.168)\end{array}$ & $\begin{array}{l}-0.832 * * * \\
(0.234)\end{array}$ \\
\hline Observations & 52,542 & 52,542 & 52,542 & 52,542 & 52,542 & 52,542 \\
\hline Within $\mathrm{R}^{2}$ & 0.0536 & 0.176 & 0.0277 & 0.00278 & 0.106 & 0.0195 \\
\hline Adjusted $\mathrm{R}^{2}$ & 0.946 & 0.565 & 0.907 & 0.659 & 0.516 & 0.769 \\
\hline
\end{tabular}

Panel B: Full sample

\begin{tabular}{|c|c|c|c|c|c|c|}
\hline \multicolumn{3}{|l|}{$\operatorname{TaxD}_{t}$} & \multirow[t]{2}{*}{$\begin{array}{l}0.170 \\
(0.196)\end{array}$} & \multirow[t]{2}{*}{$\begin{array}{l}-\mathbf{- 0 . 0 9 7 8} \\
(0.215)\end{array}$} & \multirow[b]{2}{*}{$\begin{array}{l}-0.149 \\
(0.134)\end{array}$} & \multirow[b]{2}{*}{$\begin{array}{l}-0.512 * * * \\
(0.181)\end{array}$} \\
\hline $\operatorname{TaxD}_{t-1}$ & $\begin{array}{l}0.183 \\
(0.124)\end{array}$ & $\begin{array}{l}-0.0761 \\
(0.122)\end{array}$ & & & & \\
\hline Observations & 90,678 & 90,678 & 90,678 & 90,678 & 90,678 & 90,678 \\
\hline Within $\mathrm{R}^{2}$ & 0.0796 & 0.129 & 0.0474 & 0.0101 & 0.0869 & 0.00810 \\
\hline Adjusted $\mathrm{R}^{2}$ & 0.939 & 0.808 & 0.906 & 0.709 & 0.760 & 0.799 \\
\hline Year FE & Yes & Yes & Yes & Yes & Yes & Yes \\
\hline Establishment FE & Yes & Yes & Yes & Yes & Yes & Yes \\
\hline Establishment controls & Yes & Yes & Yes & Yes & Yes & Yes \\
\hline Regional controls & Yes & Yes & Yes & Yes & Yes & Yes \\
\hline \multicolumn{7}{|c|}{$\begin{array}{l}\text { Notes: Regressions are calculated by OLS with establishment fixed effects and year fixed effects. Heteroscedasticity- } \\
\text { robust standard errors, which have been clustered at the establishment level, are documented in parentheses. The } \\
\text { superscripts } * * *, * * \text {, and } * \text { indicate statistical significance at the } 1 \%, 5 \% \text {, and } 10 \% \text { levels, respectively. A detailed } \\
\text { description of the dependent and independent variables is provided by Table } 1 \text {. Panel A refers to the small-group } \\
\text { sample (firms with less than } 4 \text { establishments) and Panel B refers to the full sample. }\end{array}$} \\
\hline
\end{tabular}


Table 13: Long-run effects

\begin{tabular}{|c|c|c|c|c|c|c|c|}
\hline MODEL & $(1)$ & (2) & (3) & $(4)$ & $(5)$ & $(6)$ & $(7)$ \\
\hline Dependent variable $\mathrm{Y}_{\mathrm{t}}$ & $\begin{array}{l}\text { Payroll } \\
\text { share }\end{array}$ & $\begin{array}{l}\text { Employee } \\
\text { share }\end{array}$ & $\begin{array}{l}\text { Hours per } \\
\text { employee } \\
\text { ratio }\end{array}$ & $\begin{array}{l}\text { Sales } \\
\text { share }\end{array}$ & $\begin{array}{l}\text { Investment } \\
\text { share }\end{array}$ & $\begin{array}{l}\text { Payroll per } \\
\text { hour ratio }\end{array}$ & $\begin{array}{l}\text { Payroll per } \\
\text { sales ratio }\end{array}$ \\
\hline \multicolumn{8}{|c|}{ Short run effects (as also documented by Table 9 and Table 11) } \\
\hline $\operatorname{TaxD}_{\mathrm{t}}$ & $\begin{array}{l}-0.657 * * * \\
(0.212)\end{array}$ & $\begin{array}{l}-0.118 \\
(0.176)\end{array}$ & $\begin{array}{l}-0.633 * * * \\
(0.178)\end{array}$ & & & $\begin{array}{l}-0.545^{* * *} \\
(0.204)\end{array}$ & $\begin{array}{l}-1.310 * * * \\
(0.280)\end{array}$ \\
\hline $\operatorname{TaxD}_{\mathrm{t}-1}$ & & & & $\begin{array}{l}-0.0962 \\
(0.189) \\
\end{array}$ & $\begin{array}{l}-0.529 * * \\
(0.251) \\
\end{array}$ & & \\
\hline \multicolumn{8}{|l|}{ Long run effects } \\
\hline $\operatorname{TaxD}_{\theta}$ & $\begin{array}{l}-0.814 * * * \\
(0.258)\end{array}$ & $\begin{array}{l}-0.0346 \\
(0.239) \\
\end{array}$ & $\begin{array}{l}-0.554 * * * \\
(0.215)\end{array}$ & & & $\begin{array}{l}-0.576 * * \\
(0.247)\end{array}$ & $\begin{array}{l}-1.299 * * * \\
(0.342)\end{array}$ \\
\hline $\operatorname{TaxD}_{\theta-1}$ & & & & $\begin{array}{l}-0.248 \\
(0.293)\end{array}$ & $\begin{array}{l}-0.632 * \\
(0.349)\end{array}$ & & \\
\hline Establishment controls & No & No & No & No & No & No & No \\
\hline Year FE & Yes & Yes & Yes & Yes & Yes & Yes & Yes \\
\hline Establishment FE & Yes & Yes & Yes & Yes & Yes & Yes & Yes \\
\hline Regional Controls & Yes & Yes & Yes & Yes & Yes & Yes & Yes \\
\hline Observations & 50,196 & 50,196 & 50,196 & 42,620 & 42,620 & 50,196 & 50,196 \\
\hline Within $\mathrm{R}^{2}$ & 0.00515 & 0.00216 & 0.172 & 0.00596 & 0.00396 & 0.0993 & 0.00631 \\
\hline Adjusted $\mathrm{R}^{2}$ & 0.892 & 0.945 & 0.892 & 0.913 & 0.669 & 0.513 & 0.770 \\
\hline
\end{tabular}

Notes: Regressions are calculated by OLS with establishment fixed effects and year fixed effects, but without establishment controls. Heteroscedasticity-robust standard errors, which have been clustered at the establishment level, are documented in parentheses. The superscripts ***, **, and * indicate statistical significance at the $1 \%, 5 \%$, and $10 \%$ levels, respectively. Long-run effects are calculated as documented by Subsection 5.3. 